УДК $94(477.83 / .86)$

\title{
ПЕРШІ КОНТАКТИ ПАНТЕЛЕЙМОНА КУЛІША З ГАЛИЧИНОЮ (1858-1865 рр.)
}

\author{
Ігор РАЙКІВСЬКИЙ \\ Державний вищий навчальний заклад \\ "Прикарпатський національний університет імені Василя Стефаника" \\ кафедра історії України і методики викладання історії \\ вул. Шевченка, 57, 76018, Івано-Франківськ, Україна \\ e-mail:i.raj@ukr.net \\ DOI: $10.15330 /$ gal.33.72-92 \\ ORCID: 0000 0003-2218-9556
}

\begin{abstract}
У статті висвітлюються контакти Пантелеймона Куліша з Галичиною, щзо охоплюють період від першого приїзду украӥнського письменника $і$ громадського діяча до Львова влітку 1858 р. $i$ до переходу на державну службу наприкінці 1864 р. та появи останніх публікацій у часописах “ранніх" народовців на початку 1865 р. П. Куліш відіграв особливу роль в утвердженні украӥнської начіональної ідеї серед галичан, особливо в 1867 p. - на початку 1870-х рр., підтримував діяльність місиевих народовиів. Значну увагу звернено на листування П. Куліша з Я. Головацьким після знайомства в 1858 р., його взаємини з лідерами народовців Д. Танячкевичем і К. Климковичем, русофілом Б. Дідицьким та ін. Різножанрові твори П. Куліша - як нові, так і раніше опубліковані, насамперед з альманаху “Кіевлянинъ” 1840 i 1841 рp. та петербурзького журналу “Основа” (1861-1862 рр.) - регулярно друкувалися в народовській пресі у Львові часописах “Вечерниці" (1862-1863 рр.), “Мета” (1863-1865 рр.) і “Нива” (1865 р.). Водночас П. Куліш друкувався в русофільських виданнях - газеті “Слово” і літературному збірнику “Галичанинъ”, що на початку 1860-х рр. проявляли інтерес до нової украӥнської літератури. Кулішеві зв'язки з галицькими діячами перервалися після його призначення російським чиновником у Варшаві в умовах посилення антиукраӥнських репресій иаризму та внутрішньої кризи в діяльності галицьких народовців. 3 новою силою інтерес П. Куліша до Галичини проявився з 1866 р.
\end{abstract}

Ключові слова: Пантелеймон Куліш, украйнський діяч, Галичина, контакти, часопис, народовці, русофіли.

Ключову роль в українському відродженні (модерному націотворенні) XIX - початку XX ст. відіграло утвердження в масах новочасної національної самосвідомості, що стало заслугою передової інтелігенції у складі двох імперій - Російської та Австрійської (АвстроУгорської). Відносини між українською інтелігенцією обабіч австро-російського кордону одне 3 ключових питань історії України імперського періоду ${ }^{1}$. Особливу роль в утвердженні української національної ідеї серед галицьких русинів відіграли три видатні громадські діячі П. Куліш, М. Драгоманов і М. Грушевський. І. Франко писав про “представників трьох різних поколінь" у розвитку українського руху в австрійській Галичині, вплив яких “поширився здебільшого між інтелігенцією, а частково й між народом: у 60-х роках XIX ст. домінував вплив Куліша, у 70-х (із середини десятиліття. - I. P.) і 80-х - Драгоманова, а в 90-х - Грушевського”. На думку I. Франка, перший напрям був “формально національним (його ще називають національнокультурницьким. - I. P.), другий - радикально-соціальним і третій - національно-радикальним"”2. Іншим разом І.Франко назвав П. Куліша “головним двигачем українофільського руху в Галичині в 60-х і майже до половини 70-х років"3.

\footnotetext{
1 Мудрий М. Національно-політичні орієнтації в українському суспільстві Галичини австрійського періоду у висвітленні сучасної історіографії. Вісник Львівського університету. Серія історична. Львів, 2002. Вип. 37. Ч. 1. С. 497, 498.

${ }^{2}$ Франко І. Українці. Зібрання творів : у 50-ти т. Київ, 1984. Т. 41. С. 189.

${ }^{3}$ Франко I. Писання І. П. Котляревського в Галичині. Зібрання творів : у 50-ти т. Київ, 1981. Т. 31. C. 333 .
} 


\section{Проблеми нової і новітньої історії}

Стаття $є$ продовженням циклу публікацій автора про ідейний вплив П. Куліша на Галичину та його взаємини 3 краянами ${ }^{4}$. Автор поставив за мету проаналізувати Кулішеві контакти 3 галицькими діячами в кінці 50-х - першій половині 60-х pp. XIX ст., що хронологічно охоплюють період від першого приїзду до Львова влітку 1858 р. і до переходу на російську державну службу у Варшаві наприкінці 1864 р. та появи його останніх публікацій у часописах “ранніх" народовців весною 1865 р. Обрана тема привертала увагу дослідників життя і багатогранної діяльності П. Куліша", але досі не була предметом окремого дослідження, викликає науковий і суспільний інтерес.

П. Куліш став “на чолі всеукраїнського національно-культурного піднесення”, за висловом дослідника його життя і творчості Є. Нахліка, ще з кінця 1850-х pp. і залишався "рушієм" українофільських настроїв серед галицьких русинів до початку 70-х pp. ${ }^{6}$. Кулішевий інтерес до народознавства пробудився під впливом видатного дослідника на ниві народознавства М. Максимовича, зокрема упорядкованого ним збірника "Малороссийские песни" 1827 р., що започаткував українську фольклористику як науку ${ }^{7}$. Історик М. Кордуба справедливо називав П. Куліша "першим апостолом єднання галичан з наддніпрянцями для спільної культурно-національної роботи”, “предтечею” українських діячів О. Кониського, В. Антоновича, М. Драгоманова і М. Грушевського, які мали найбільший вплив на національний рух у Галичині останньої третини XIX ст. ${ }^{8}$. Коротко зміст ідейної і матеріальної підтримки 3 підросійської України на адресу львівських часописів у 1860-х рр. відобразив дослідник наддніпрянськогалицьких взаємин К. Студинський: громадівці підтримували: "Вечерниці" (морально), "Слово" (дописами), "Мету”- статтями, допис(ами) і грішми (В. Білоз(ерський), Куліш), "Ниву”, "Русалку”статтями і грішми Кониськ(ого), "Правду" (1867-70 рр.) - Куліш".

3 частковою лібералізацією суспільного життя в Російській імперії наприкінці 1850-х pp. П. Куліш розгорнув багатогранну діяльність як письменник, публіцист, науковець, одна 3 чільних фігур серед петербурзької української громади. У Кулішевому збірнику “Записки о Южной Руси" (в двох томах, 1856-1857рр.) вперше було вжито для українського письма фонетичний правопис, так звану “кулішівку”, що стала кроком до української національної самоідентифікації ${ }^{10}$. "Кулішівка" більш виразно відмежовувала українську і російську мови, була прийнята в народовській пресі Галичини. У петербурзькій “друкарні П. Куліша” письменник розгорнув активну видавничу діяльність, зокрема, з-під його пера вийшов історичний роман “Чорна рада. Хроніка 1663 року” (1857 р.), “Граматка" - перший на Наддніпрянщині український буквар і читанка (1857 р., друге видання - 1861 р.) та ін. П. Куліш брав різнобічну участь у виданні в Петербурзі журналу “Основа" (1861-1862 рр.) - першого українського літературно-наукового місячника ${ }^{11}$.

\footnotetext{
${ }^{4}$ Райківський І. Внесок Пантелеймона Куліша у видання львівського журналу “Правда (1867 - початок 1870-х років). Україна : культурна спадщина, наиіональна свідомість, державність. Вип. 27 : Ювілейний збірник на пошану Юрія Сливки. Львів, 2015. С. 69-82; Його ж. Взаємини П. Куліша з галичанами в 1870-х рр. Наукові записки Тернопільського наиіонального педагогічного університету імені Володимира Гнатюка. Серія : історія. Тернопіль, 2015. Вип. 1. Част. 1. С. 44-50.

${ }^{5}$ Студинський К. Слідами Куліша. Записки НТШІ. Львів, 1928. T. CXLVIII. C. 241-306; Його ж. До історії взаємин Галичини з Україною в рр. 1860-1873. Україна. Науковий двохмісячник українознавства. Київ, 1928. Кн. 2. С. 6-40; Нахлік Є. Пантелеймон Куліш: Особистість, письменник, мислитель : у 2 т. Київ, 2007. Т. 1 : Життя Пантелеймона Куліша : Наукова біографія. 463 с. та ін.

${ }^{6}$ Нахлік Є. Пантелеймон Куліш... С.103, 245.

${ }^{7}$ Національна бібліотека України імені В. І. Вернадського НАН України. Інститут рукопису. Ф. 10 (Архів ВУАН). Од. зб. 17270. Арк. 3 .

${ }^{8}$ Кордуба М. Звязки В. Антоновича з Галичиною. Украӥна. Науковий двохмісячник украйнознавства. Київ, 1928. Кн. 5. С. 38.

${ }^{9}$ Центральний державний історичний архів України, м. Львів (далі - ЦДІАЛ України). Ф. 362 (Студинський К. - академік). Оп. 1. Спр. 141. Арк. 6.

${ }^{10}$ Нахлік Є. Пантелеймон Куліш... С. 115, 116.

${ }^{11}$ Там само. С. $119,126,133$.
} 
Захопившись українофільською ідеєю, як писалося в одному з Кулішевих листів, “до величайшего энтузиазма", письменник зав'язав тісні стосунки 3 галичанами ${ }^{12}$. П. Куліш став одним з лідерів українського громадівського руху на Наддніпрянщині в кінці 50-х - на початку 60-х pp. XIX ст. Крім Петербурга, культурно-освітні організації, гуртки-громади виникли в Києві, Полтаві, Чернігові, Одесі, Харкові та ін. Громадівці (в літературі їх ще називають “українські народолюбці”, “українофіли”, “хлопомани” та ін.) поставили за мету поширення української національної ідеї просвітницькими заходами: видавали книжки народно-розмовною мовою, заснували понад сто недільних шкіл для навчання неписьменних дорослих рідною мовою тощо. Наддніпрянські діячі звернули увагу на Галичину, що вважалася невід’ємною частиною етнічних українських земель, де необхідно було всіляко сприяти розвитку національного руху в умовах конституційних і децентралізаторських реформ у Габсбурзькій монархії в 1860-1870-х рр. П. Куліш був одним 3 перших українських діячів, які послідовно закликали до поглиблення взаємин з Галичиною.

Уперше П. Куліш побував у Галичині на початку червня 1858 р. разом із дружиною Ганною Барвінок, повертаючись на батьківщину з подорожі по Західній Європі. У Львові він познайомився $з$ колишнім діячем "Руської трійці" Я. Головацьким, якого запросив для зустрічі до себе на помешкання польський поет, історик А. Бельовський. П. Куліш був змушений прискорити повернення додому через отриманий від завідувача “друкарні П. Куліша" лист, мабуть, $з$ повідомленням про фінансову скруту ${ }^{13}$. У записці від 8 червня 1858 р., поспіхом залишеній Я. Головацькому у Львові, П. Куліш інформував про передачу "книгареві, що коло Волоськоі церкви, 35 "Граматокь”, 2 "Чорні ради”, 1 “Зап(иски) о Ю(жной) Русі” 1-го и 2-го тому и 1 Проповіді”. Автор просив отримані від продажу кошти направити на потреби Народного дому у Львові - культурно-освітньої установи галицьких русинів, що споруджувала будинок коштом всенародних пожертв, відкритий в 1864 р. До них прилучився і П. Куліш. У того ж книгаря він залишив для Я. Головацького перший том “Сочинений” М. Гоголя, два примірники “Народних оповідань” Марка Вовчка, “Літопис Самовидця” та ще якусь польську книжку ${ }^{14}$.

Не маючи достатньо коштів на повернення додому, П. Куліш купив у Львові екіпаж до м. Борзни на Чернігівщині під розписку, за сприянням Я. Головацького. На його ім'я він попросив перерахувати заборговану суму через один із львівських банків. Окрім Я. Головацького, П. Куліш міг познайомитися під час поїздки хіба що з Д. Зубрицьким. "Се були ластівки тіснійшого зближеня Українців з Росії й Галичини" повернення П. Куліш не квапився писати новому знайомому ${ }^{16}$. У начерку листа до "милого приятеля” П. Куліша від 30 червня 1859 р. Я. Головацький дорікав, що протягом року від часу знайомства не отримав жодного листа, хоча дуже просив писати йому “дещо о ході і успіхах нашої малоруської словесності і взагалі обо всім, що дотикається движенія народності малоруськоі”. Я. Головацький просив докладно інформувати про успіхи у виданні літератури народною мовою, “малоруського журналу” та ін. Водночас просив пам'ятати про галичан і не пропускати нагоди "переслати дещо із новинок літературних малоруських, а хоть би і московських, але Малорусь близько обходячих"

Я. Головацький надіслав П. Кулішеві статтю про недоцільність запровадження латинського алфавіту для русинів, що було відгомоном “азбучної війни” в Галичині 1859 р., а також просив передати видання “Проповідей” В. Гречулевича в “друкарні П. Куліша”. Галичанин

\footnotetext{
${ }^{12}$ Нахлік Є. Пантелеймон Куліш... С. 156.

${ }^{13}$ Там само. С. 199, 200.

${ }^{14}$ Львівська національна наукова бібліотека (далі - ЛННБ) ім. В. Стефаника НАН України. Відділ рукописів. Ф. 36 (Головацький Я.), Од. 3б. 213. 2 арк.; Кореспонденция Якова Головацького в лїтах 1850-62 / видав К. Студинський. Збірник фільольогічної секциї НТШ. Львів, 1905. Т. VIII. Ч. 290. С. 397.

${ }^{15}$ Гординський Я. До історії культурного й політичного життя в Галичині у 60-х рр. XIX в. Збірник фільольогічної секиії НТШ. Львів, 1917. Т. XVI. С. 21.

${ }^{16}$ Нахлік Є. Пантелеймон Куліш і “Руська трійця”. До проблеми ідеологічних шукань серед української інтелігенції ХІХ століття. Львів, 1994. С. 6.

${ }^{17}$ Кореспонденция Якова Головацького в лїтах 1850-62. Ч. 344. С. 463. Оригінал листа див.: ЛННБ ім. В. Стефаника. Відділ рукописів. Ф. 36. Од. зб. 508. 2 арк.
} 


\section{Проблеми нової і новітньої історії}

висловив пропозицію щодо співпраці у підготовці замовленої австрійським міністерством для гімназій хрестоматії нової української літератури від часів І. Котляревського. Видаючи "хрестоматію малоруськую", він мав намір помістити кращі твори письменників, які представили б “світу всі прекраснії цвіти малоруської левади”. Книжка буде підручником для багатьох поколінь, “возбудить народні таланти”. Уміщені в ній тексти мають привернути увагу освіченої молоді, бути за формою “прекрасні” й за змістом “важні”. Упорядник планував подати в хрестоматії короткі біографії українських письменників, чого не міг зробити без братньої допомоги 3 Наддніпрянщини. "Пособіть, брате, русинам галицьким, - відверто закликав Я. Головацький, засиліть їх плодами малоруської братії, бо наша самотня билинка засхне від спеки, або приглушать іiі сусіднії бур'яни”. Він із радістю писав, що Народний дім у Львові “славно будується" і тут же бідкався: "У нас в літературі мало що появляється""

Найбільш важливим питанням для галицьких русинів Я. Головацький вважав правописне, рішуче виступив проти насаджуваної урядом латинки, що нібито зможе зберегти "від впливу московщини і церковного язика і управляти чисту русчину”. Він вбачав реальну небезпеку у відриві рідної словесності "від кореня історичного", застерігав, щоб через переведення письма 3 кириличного на латинський алфавіт "не зниділа зовсім наша Русь або не злялася 3 ляцькою (польською. - I. P.) літературою, боїмося і за віру нашу гречеськую, щоби ії не залляло латинство, боремся, як можем, і готові до посліднього защищати нашу старовину”. Водночас образно говорилося про мовно-культурну єдність галицьких русинів з “українським співцем”, щоб разом заспівати пісню про подолання усіх "невзгодин" 19 . Я. Гординський вважав цей лист Я. Головацького “свойого рода епохальною подією” у взаєминах галичан із підросійською Україною. Звернувшись до наддніпрянської інтелігенції, “малоруської братії”, Я. Головацький висловив прохання надсилати літературу в Галичину, щоб національно-культурне життя в краї не завмерло. Мабуть, це вплинуло “на амбітного Куліша", викликавши в нього бажання “відіграти роль духовного провідника в Галичині”,20.

Після особистого знайомства 3 Я. Головацьким П. Куліш активізував стосунки з галичанами на початку 1860 -х рp. і відіграв особливу роль у загальноукраїнському національному русі. Перша Кулішева поїздка до Львова 8 червня 1858 р., за словами К. Студинського, “була початком єднання Куліша з Галичиною", ластівкою "тіснішого зближення українських діячів 3 галицькими" 21 . П. Кулішу судилося зробити “почин”, як згадував пізніше О. Барвінський, один 3 промоторів наддніпрянсько-галицького єднання в останній третині XIX ст., до встановлення “сталих взаємин між Галичиною [i] закордонною Україною"22. К. Студинський вважав, що П. Куліш не відгукнувся на лист Я. Головацького в червні 1859 р. (“між багатою перепискою Головацького не найшли ми сліду якої-небудь відповіди" ${ }^{23}$. Однак у відділі рукописних фондів і текстології Інституту літератури ім. Т.Г. Шевченка НАН України (м. Київ) збереглися листи П. Куліша до Я. Головацького від 29 жовтня 1859 р. і 20 лютого 1860 р.

У першому листі 29 жовтня 1859 р., написаному з Москви, П. Куліш підтримав ідею видання хрестоматії української літератури ("Хрестоматія святе діло! Нехай Богъ вамъ помогае! ... На всяку працю для сёго діла готовъ”) ${ }^{24}$, але наполягав, щоб підготувати ії “кулішівкою”

\footnotetext{
${ }^{18}$ Головацький Я. До П. Куліша (1859). Письменники Західної України 30-50-х років XIX cm. / упоряд., підготовка текстів I. І. Пільгука та М. Г. Чорнописького. Київ, 1965. С. 294, 295; Кореспонденция Якова Головацького в лїтах 1850-62. Ч. 344. С. 463, 464.

${ }^{19}$ Головацький Я. До П. Куліша (1859). Письменники Західної України 30-50-х років XIX cm... С. 295; Кореспонденция Якова Головацького в лїтах 1850-62... Ч. 344. С. 464.

${ }^{20}$ Гординський Я. До історії культурного й політичного життя в Галичині у 60-х рр. ХІХ в... С. 22.

${ }^{21}$ Студинський К. До історії взаємин Галичини з Україною в pp. 1860-1873. Україна. Науковий двохмісячник українознавства. Київ, 1928. Кн. 2. С. 16.

${ }_{22}$ Барвінський О. Спомини 3 мого життя. T. II. Ч. III, IV / упоряд. А. Шацька; комент. Б. Янишина; ред. Л. Винар, М. Жулинський. Нью-Йорк ; Київ, 2009. С. 40.

${ }^{23}$ Студинський К. Слідами Куліша. Записки НТШ. Праиі історично-філологічної секиії. Львів, 1928. T. CXLVIII. C. 243.

${ }^{24}$ Інститут літератури ім. Т. Г. Шевченка. Відділ рукописних фондів і текстології, м. Київ. Ф. 104 (Головацький Я.). Од. зб. 689. Арк. 1.
} 
(“нашою правописсю, такъ якъ почавъ я и зъ мене другі печататись”). Лист був переповнений самостійницькими прагненнями, автор просив називати себе і колег по перу "писателями украінськими, або южно-руськими, бо то Москалі выдумали величати себе великими, а нась малими. Слоняка більший одъ чоловіка, а все чоловікъ не мале существо моральне”. П. Куліш виступив проти вживання етноніму малорус (“малоруссь”) 25 , писав про заходи щодо видання в Петербурзі українського журналу "Основа" й обіцяв надсилати галичанам наддніпрянські книжки “зъ дорогою душею!". У листі говорилося, з одного боку, про здобутки на шляху формування української літературної мови, а з іншого, про те, що “успіху мало мають мои книжки у торгу” 26 .

У листі 20 лютого 1860 р. П. Куліш з Петербурга знову висловився за видання хрестоматії кращих творів українських письменників: “Колись будемо всі вкупі, то треба, щобъ Ваши читателі набирались нашого смаку". На його думку, українські письменники Наддніпрянщини перевершили галичан, а їх твори можуть бути зразком для наслідування. Було піддано критиці тих, хто помалу зрікається рідного слова на бік московщини, з цього “добра не буде, бо наша украінська словесность до віку вічнёго зъ нею не помиритця. Та мова... тілько недавніми часами почала спускатись унизъ до людей простихъ, а наша - родилась и зацвіла въ сільскій хаті..."27. Очевидно, малося на увазі, що українська літературна мова, на відміну від російської, формувалася “знизу”, через входження простонародної мови в літературу. П. Куліш не сумнівався, що рано чи пізно запанує замість “казенноі Московщини вольная річь Украінська", тож радив галичанам заздалегідь наближати свою книжну словесність “до одного смаку зъ нашою, а Московську вважати за чужосторонню”. Водночас він жалівся на переслідування царизмом української мови: “Журнала украінського не дозволяють”28.

3 короткої фрази на початку Кулішевого листа від 20 лютого 1860 р. (“писали Ви до мене листь черезъ пана Смирнова ..., я заразъ Вамъ одписавъ, тілько наврядъ чи дойшло до Вашихъ рукъ моє писаннє") ${ }^{29}$ можна зробити висновок, що переписка між П. Кулішем і Я. Головацьким продовжувалася після їх знайомства влітку 1858 р. Між двома українськими діячами обабіч австро-російського кордону зав'язалися ділові й суто людські контакти: вони листувалися, обмінювалися літературою (до розриву в 1866 р., що було пов'язано з відкритим переходом Я. Головацького в москвофільський табір $)^{30}$. П. Куліш піклувався про постачання українських видань Я. Головацькому та львівському купцю і меценату М. Димету, що співпрацювали із завідувачем “друкарні П. Куліша” Д. Каменецьким ${ }^{31}$. О. Барвінський зауважив, що після ближчого знайомства з П. Кулішем у серці Я. Головацького "наново відізвалась... заглушена Погодіним (у 1850 -х рр. - I. Р.) українська свідомість...,"32, розуміння мовно-культурної та історичної єдності галичан з наддніпрянськими українцями, а не 3 широким панруським простором.

Я. Головацький відповів П. Кулішу на листа, написаного в лютому 1860 р., після деякої перерви, як зауважив, “не квапився писати до Васъ”. У листі 10 (22) вересня 1860 р. він скаржився на польський наступ у Галичині, писав про надумані звинувачення в промосковських симпатіях місцевого руського населення: “Ляхи... оббрехали нашихъ що найголовнъйшихъ Русиноิвъ, що мы нибы съ Москалями переморгуемося, то треба було и тъни своеи страхатися”. Критично говорилося про урядову спробу в 1859 р. перевести "руську" мову на латинку, зневажливо названу чешсько-латинською "какографією”, але "все руское племя... одстояло свое достояніе" ${ }^{33}$. Водночас у відповіді Я. Головацького містилися яскраво виражені симпатії до

\footnotetext{
${ }^{25}$ Інститут літератури ім. Т. Г. Шевченка. Відділ рукописних фондів і текстології, м. Київ. Арк. 2.

${ }^{26}$ Там само. Арк. 1, 1 зв.

${ }^{27}$ Там само. Од. зб. 690. Арк. 1.

${ }^{28}$ Там само. Арк. 1 зв.

29 Там само. Арк. 1.

${ }^{30}$ Нахлік Є. Пантелеймон Куліш і “Руська трійця”... С. 5, 24.

${ }^{31}$ Нахлік Є. Пантелеймон Куліш... С. 205.

32 Барвінський О. Спомини з мого життя... Т. II. Ч. III, IV. С. 40.

33 Інститут літератури ім. Т. Г. Шевченка. Відділ рукописних фондів і текстології, м. Київ. Ф. 104. Од. зб. 242. Арк. 1, 1 зв.
} 


\section{Проблеми нової і новітньої історії}

Росії. “Дякуйте той проклинаемой Вами Московщинъ, - писав він П. Кулішу, - що Васъ выдвинула на таку высоту воззрђнія, ... до созерцанія чистой народности"з4. Іншим разом у 1860 р. Я. Головацький висловлював необхідність поглиблення наддніпрянсько-галицьких взаємин, щоб, за його словами, "Вы читали всњ наши изданія, а мы получали всь книжки и статьи", написані “по южно-русски", тобто українською мовою, з історії “южной Руси"35.

Десь у кінці 1860 р. або в січні 1861 р. Я. Головацький надіслав П. Кулішеві програму русофільської газети “Слово", що почала виходити у Львові, декілька галицьких видань, зокрема поему Б. Дідицького “Буй-Туръ Всеволодъ” (1860р.). Посилку супроводжував лист Я. Головацького, у якому той питав про петербурзьку “Основу” ". У відповідь П. Куліш 28 січня 1861 р. 3 Петербурга висловив надію на подальшу співпрацю з галичанами, що сприяла б формуванню єдиної української літературної мови. Однак, категорично не сприйнявши макаронічне "язичіє”, яким була написана частина надісланих книжок з Галичини, він дорікав Я. Головацькому: "Чомъ се Ви, панове братья, не хапаетесь нашоі мови, а пишете на взіръ того, якъ у насъ колись писали въ академияхъ... У насъ изъ Вами виходить не одна, а дві літератури. Ваша словесность така жъ одъ нашоі далека, якъ и московська. И правопись Ваша якась чудна, що хто не бувъ у Васъ и не чувъ, якъ Ви вимовляєте, то читатиме Ваши книжки по-московськи”. Автор просив звернути увагу видавців “Слова" на свою критику ${ }^{37}$.

У листі-відповіді 8 (20) червня 1861 р. Я. Головацький обійшов мовчанкою Кулішеві зауваження, просив тільки надсилати петербурзьку “Основу” та українські книжки (“звъстка о выходящей "Основъ” прошибнула цьлу краину нашу и зо всьхъ сторонъ попытують мене, якъ бы можна достати тую книжку”). Галичанин обіцяв своє посередництво у взаємообміні й літературному спілкуванні, писав про активізацію в краї національного руху: "У насъ теперь сильно двигнулася народность и литература поступае жваво впередъ, ... треба отворити безпереривны зношенія межи собою и литературное общеніе”. Галицький діяч радів поступам у розвитку літератури живою народною мовою і дав пораду наддніпрянцям читати львівське "Слово" (“Вамъ бы конечно здалося читати наше “Слово”, но бъда не знать, як переслати Вамъ...”) 38 . Мабуть, Я. Головацький не отримав відповіді від П. Куліша, що підтверджує його лист редакторові В. Білозерському 30 січня 1862 р., надрукований у журналі “Основа"39. У листі Я. Головацький, поряд із віршем народовця В. Шашкевича для публікації (“стишокъ молодого, даровитого півця нашого" $)^{40}$, передавав привіт П. Кулішу і його дружині, з радістю писав про активізацію національного життя в Галичині, що “еще не вмерла козацькая руськая мати!” 41 .

У русофільському літературному збірнику “Галичанинъ” 1862 р., що виходив у Львові, Я. Головацький помістив список українських книжок, надісланих, на його прохання, завідувачем “друкарні П. Куліша" Д. Каменецьким у Петербурзі, де друкувалася “Основа”, до Ставропігійської книгарні в жовтні 1862 р. (усього - 52 позиції) ${ }^{42}$. Тут, зокрема, були випущені окремими виданнями твори П. Куліша й упорядковані ним збірники: “Записки о Южной Руси”, історичний роман "Чорна рада", "Граматка", чотиритомник Кулішевої російськомовної прози "Повъсти” (1860р.), альманах "Хата", історико-популярний нарис “Хмельнищина” тощо. Серед

\footnotetext{
34 Інститут літератури ім. Т. Г. Шевченка. Відділ рукописних фондів і текстології, м. Київ. Ф. 104. Од. зб. 242. Арк. 1 зв., 2.

${ }^{35}$ Там само. Од. зб. 243. Арк. 1 зв.

${ }^{36}$ Студинський К. Слідами Куліша... С. 243.

${ }^{37}$ ЦДІАЛ України. Ф. 309 (НТШ, м. Львів). Оп. 1. Спр. 2296. Арк. 2; Студинський К. Слідами Куліша... C. 250.

${ }^{38}$ Студинський К. Слідами Куліша... С. 251.

39 Частина листу високоповажного профессора ві Львовськімъ університеті Якова Өедоровича Головацького до редактора (30-го січня 1862 р.). Основа. 1862. Липець (іюль). С. 68.

${ }^{40}$ Шаськевичъ В. Нинішня наша пісня (Стихъ голошений при отвореню "Руськоі Бесіди” въ "Народнімъ Домі” ві Львові, дня 9/21 января 1862 г.). Там само. С. 69-72.

${ }^{41}$ Частина листу... Там само. С. $68,69$.

42 Украинска словесность. Галичанинъ. Литературный сборникъ, издаваемый Я. Ө. Головаикимъ и Б. А. Дгъдиикимъ. Львовъ, 1862. Кн. 1. Вып. 1. С. 190-193.
} 
літератури, яку пропонувалося придбати в Галичині, був журнал “Основа” за 1861 i 1862 pp. ${ }^{43}$. Редакція констатувала прагнення "къ ближайшому сообщенью литературному съ закордонскою Мало-Русію" в контексті поглиблення "взаимности славянской...", інтерес до літератури, що надходила 3 підросійської України: “Читанье русскихъ книжокъ, якого бы они ни были содержанья и формы, сталось уже у насъ необходимою потребою ...,44.

Листування П. Куліша з Я. Головацьким, започатковане на зламі 50-60-х pp. XIX ст., перервалося на декілька років (до лютого 1866 р.) ${ }^{45}$. На початку 1860-х рр. П. Куліш мав більш тісні стосунки з редактором “Слова” Б. Дідицьким. На відміну від Я. Головацького, один 3 ідеологів русофільства в Галичині Б. Дідицький демонстрував тоді більшу толерантність до українофільських поглядів. Він з симпатією писав про Т. Шевченка, назвавши його “настоящій украинець”. До редакції львівського часопису в 1860-х рр. заходили, за словами Б. Дідицького, "малорусини", наукові й громадські діячі, що приїжджали в Галичину з Наддніпрянщини, зокрема в 1861 р. - П. Лавровський і С. Гогоцький, в 1863 р. - М. Барсов, учень М. Костомарова, та О. Потебня, в 1865 р. - Ф. Лебединцев та ін. ${ }^{46}$. Впадає у вічі, що це були представники різних ідейних напрямків: частина з них (О. Потебня, І. Лашнюков, М. Барсов та ін.) прихильно ставилися до української мови і культури, тоді як, для прикладу, С. Гогоцький був прихильником “книжного общерусского языка", російської літературної мови.

Я. Головацький писав до П. Куліша його правописом, “кулішівкою”, тоді як у тодішньому листуванні із земляками-галичанами відкрито проявляв симпатії до російської літературної мови. На ідейну еволюцію Я. Головацького в москвофільський табір мала вплив кореспонденція 3 прихильниками загальноруської єдності, українофобами з Росії С. Гогоцьким і К. Говорським. Так, професор Київського університету С. Гогоцький у листі в серпні 1863 р. вказав на дві найбільші помилки видавців "Слова": пропаганду “какой-то Украйны, ... слушаясь различных Кулишей, людей очень недалеких", та ігнорування редакцією шляхів наближення місцевої говірки до літературної російської мови. Адресант радив Я. Головацькому триматися "одного

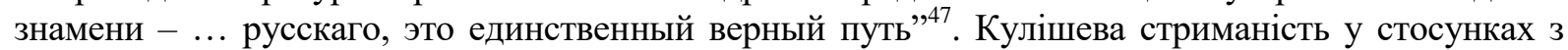
Я. Головацьким сприяла еволюції останнього в бік відверто ворожих українофільству поглядів у 1860-х pp. ${ }^{48}$. Ідейна еволюція Я. Головацького відбулася в умовах антиукраїнських репресій у Росії за Валуєвським циркуляром 1863 р., а з другого боку, перетворення Галичини практично в польську автономну провінцію Габсбурзької монархії в 1860-х рр., що спроневірювало частину місцевої інтелігенції в перспективи розвитку українського національного руху.

Як наддніпрянський громадівець П. Куліш встановив найбільш тісні зв’язки з галичанами в першій половині 1860 -х рp. Він зблизився 3 народовськими діячами, що організаційно оформилися під ідейним впливом з Наддніпрянщини і вбачали галицьких русинів невід’ємною частиною єдиного українського, “малоруського” народу, на відміну від росіян-“великоросів" і поляків. П. Куліш встановив регулярні товариські стосунки з "ранніми” народовцями в Галичині, закликав місцеву молодь до самовідданої праці на благо рідного народу. П. Куліш обмінювався листами $з$ лідерами народовців Д. Танячкевичем, К. Климковичем та ін. Так, Кулішеве листування з студентом Львівської духовної семінарії Д. Танячкевичем (псевдонім - Будеволя) почалося восени 1861 р. Від українського діяча він отримував книжки, що поширювалися серед галицьких народовців у семінарії, мав контакти 3 т. зв. "вечерничниками" - народовською громадою, згуртованою навколо часопису "Вечерниці", 4 . К. Студинський 3 жалем писав, що “багато з тих листів... безповоротно затратилося" "

\footnotetext{
${ }^{43}$ Украинска словесность... С. 192, 193.

${ }^{44}$ Славянская библиографія... С. 187, 188.

${ }^{45}$ ЦДІАЛ України. Ф. 309. Оп. 1. Спр. 2296. Арк. 5, 6; Студинський К. Слідами Куліша... С. 244.

${ }^{46}$ Своежитьевыи записки Богдана А. Дьдицкого. Ч. I : Где-що до исторіи саморозвитія языка и азбуки Галицкой Руси. Львовъ, 1906. С. 48, 56, 61, 62, 67.

${ }^{47}$ ЦДІАЛ України. Ф. 362. Оп. 1. Спр. 97. Арк. 48.

${ }^{48}$ Нахлік Є. Пантелеймон Куліш і “Руська трійця”... С. 10, 11.

${ }^{49}$ Студинський К. Слідами Куліша... С. 280.

${ }^{50}$ Студинський К. До історії взаємин Галичини з Україною в рр. 1860-1873... С. 29.
} 


\section{Проблеми нової і новітньої історії}

П. Куліш мав особливий вплив на видавничу діяльність "ранніх" народовців у Галичині, не лише надсилав власні твори для публікації в часописах "Вечерниці" (1862-1863рp.) і “Мета" (1863-1865 pр.), але й залучав до друку наддніпрянських авторів. Народовці радо вміщували на сторінках своїх часописів раніше опубліковані Кулішеві твори. Незадоволений цензурними умовами в Російській імперії та редагуванням петербурзької “Основи”, П. Куліш висунув думку про можливість використання галицької періодики як трибуни для українських письменників Наддніпрянщини. Зусилля П. Куліша були спрямовані на перетворення Галичини в плацдарм загальноукраїнського культурного розвитку ${ }^{51}$. У свою чергу, інтерес галичан до українського руху пояснювався браком висококваліфікованих наукових сил і достатніх матеріальних ресурсів для власної національної самоідентифікації, в боротьбі з домінуючими в краї польськими впливами (як політико-ідеологічний інструмент) ${ }^{52}$. Так, у листі до С. Карпенка О. Барвінський відверто писав у 1868 р.: "Ніхто не вглубився въ душу нашого народу, якъ Костомаровъ и Кулішъ. Вони оба студиювали ёго язикъ, ёго звичаі и обичаі, ёго историюминувшість" ${ }^{53}$.

Наддніпрянська література мала визначальний вплив на українське національне самоусвідомлення галицьких русинів, що були змушені визнати самі народовські діячі. Так, В. Шашкевич, син Маркіяна Шашкевича, один із лідерів "ранніх" народовців, згадував в автобіографії, що після ознайомлення з літературним альманахом "Хата", виданим під редакцією П. Куліша в Петербурзі 1860 р., він переконався в органічності українства для галичан (“се не утопія"). В альманасі, зокрема, друкувалися твори П. Куліша, Т. Шевченка, С. Гребінки, Марка Вовчка та ін. В. Шашкевич вирішив "іти дальше дорогою, витиченою нам українськими писателями, та й “Дністровою Русалкою"і "Вінком" (“Вінок русинам на обжинки". - I. P.)",54. О. Барвінський писав у спогадах, що крім Шевченкового "Кобзаря", якого знав майже напам'ять, уважно вивчав творчість П. Куліша (“Записки о Южной Руси”) та інших наддніпрянських письменників - Марка Вовчка, І. Котляревського, Г. Квітки-Основ'яненка, зміст журналу "Основа" i "робив собі виписки не тілько рідше уживаних слів, але й зворотів та гарних уступів в тих творах", навчився багато “українських висловів..., 55 .

Твори П. Куліша - як нові, так і раніше опубліковані - регулярно друкувалися на сторінках часописів "ранніх" народовців у Львові “Вечерниці" (1862-1863рр.), “Мета" (18631865 рр.) і “Нива” (1865р.). За посередництвом Д. Танячкевича і К. Климковича П. Куліш встановив безпосередні зв'язки з народовцями, що зайнялися виданням журналів "Вечерниці" та "Мета", в літературі діячів цієї громади називають "вечерничниками" "56. Редакція "Вечерниць", поряд з творами галичан В. Шашкевича, К. Климковича, С. Згарського, Ф. Заревича, Д. Танячкевича та ін., буковинця Ю. Федьковича ${ }^{57}$, друкувала творчий доробок українських діячів 3 Наддніпрянщини, що був зразком для наслідування. Власними силами “вечерничники” навряд чи змогли б заповнити журнал "своїми творами, - писав К. Студинський, - якби не особисті зв'язки з українськими письменниками, якби не журнали “Кіевлянинъ”(1840 і 1841 рр.) i “Основа"(1861-2), а побіч них видання творів поодиноких авторів ...."58. Крім П. Куліша, серед найбільш популярних наддніпрянських письменників були Т. Шевченко, Марко Вовчок, Л. Глібов, О. Стороженко, В. Бернатович (Кузьма Басарабець) та ін.

\footnotetext{
${ }^{51}$ Нахлік Є. Пантелеймон Куліш... С. 203, 204; Дорошенко Д. Пантелеймон Куліш. Київ ; Ляйпціг, [б. р.]. C. 36 .

${ }^{52}$ Мудрий М. Формування новочасної національно-політичної культури українського суспільства Галичини (проблема зовнішніх моделей). Вісник Львівського університету. Серія історична. Львів, 2003. Вип. 38. С. 140, 141.

${ }^{53}$ Студинський К. Галичина й Україна в листуванні $1862-1884$ pp. Матеріяли до історії української культури в Галичині та тї зв'язків з Україною. Харків ; Київ, 1931. С. 46.

${ }_{55}^{54}$ Возняк М. Недрукована автобіографія Володимира Шашкевича. Недїля. 1911. № 35.10 вересня. С. 6.

${ }^{55}$ Барвінський О. Спомини 3 мого життя. Ч. І-ІІ / упоряд. А. Шацька, О. Федорук; ред. Л. Винар, І. Гирич. Нью-Йорк ; Київ, 2004. С. 85.

${ }^{56}$ Нахлік Є. Пантелеймон Куліш... С. 204.

${ }^{57}$ ЦДІАЛ України. Ф. 362. Оп. 1. Спр. 74. Арк. 57, 58.

${ }^{58}$ Там само. Спр. 94. Арк. 91.
} 
П. Куліш підписувався власним іменем або як Петро Забоцень, Хуторянин, Т. Вешняк ${ }^{59}$. Він надіслав до “Вечерниць” оповідання “Дівоче серце”, що було надруковано в листопаді грудні 1862 р. (ч. 39-42) (00 приміткою редакції: “Помъщаючи повђсть “Дівоче серце”, дякуємо Пану Кульшеви за честь, яку зробивъ намъ, пересылаючи свою працю у нашу Редакцію. При щироิй помочи надднЊпрянськихъ братоิвъ чей скорше зайдемо тамъ, куда давно намъ прямовати належало.., побачимо всњ одинъ цђль, одну дорогу сынамъ великои Украины”. Редакція вирішила не змінювати правопису П. Куліша “для вигоды нашои старшои читающои публики", . Невдовзі після публікації у “Вечерницях" “Дівоче серце” вийшло окремим виданням у Львові “коштомъ руськихъ семинаристівъ” 1862 р. (31с.) $)^{62}$. У народовському часописі побачили світ дві Кулішеві поезії “До братів на Вкраїну"63 і дума "Кумейки",64, що були передруковані. На прохання видавців надіслати нові твори П. Куліш відповів: “Шкода, що не маю нічого готового послати Вамъ у збірникъ; а тільки що напишу, заразъ и вишлю. [...] Щиримъ серцемъ прихильний до Васъ и до всеі коханоі Галицькоі Русі"б5 .

На жаль, архів "Вечерниць” майже не зберігся, хоч у часописі згадувалося про листування 3 редакцією українських авторів, включаючи П. Куліша ${ }^{66}$. Запрошуючи до передплати часопису на 1863 р., львівські видавці запевняли, що знайшли “симпатію въ народъ межи старшими и молодшими, въ Галичь и на Украинъ”. Підтвердженням цього були “численни листы, яки доิстаємо зъ провинціи, и матеріялы, якихъ удалось намъ нагромадити посльдними часами...."67. Щоправда, зв'язки наддніпрянських письменників i простих дописувачів 3 редакцією були спорадичними, водночас не вдалося знайти докладних відомостей про матеріальну допомогу для “Вечерниць” 3 підросійської України ${ }^{68}$. К. Студинський стверджував, що, крім П. Куліша, в безпосередній переписці з “Вечерницями” залишалися маловідомі літератори В. Бернатович і М. Терезовський, тоді як твори інших українських письменників надходили, найімовірніше, “з другої руки” - від самого П. Куліша. або передруковувалися ${ }^{69}$. Більшість праць, які побачили світ у “Вечерницях”, були передруковані з двох журналів - М. Максимовича “Кіевлянинъ” (далі “Киевлянин”) видання 1840 i 1841 рр. та В. Білозерського “Основа” в Петербурзі (1861-1862 pp.), 3 якого, за висловом К. Студинського, “редакція черпала повними пригорщами”, .

К. Климкович переклав з альманаху “Киевлянин” 1840 р. російськомовні оповідання П. Куліша, що побачили світ у "Вечерницях",71. 3 другої книги 1841 р. була передрукована в перекладі К. Климковича Кулішева повість “Огняний змій”72. Редакція “Вечерниць” містила

\footnotetext{
${ }^{59}$ Студинський К. До історії взаємин Галичини з Україною в рр. 1860-1873... С. 25; Дей О. І. Словник українських псевдонімів та криптонімів (XVI-XX ст.). Київ, 1969. С. 160, 385.

60 Дівоче серце. Идилія П. Куліша. Вечерницъь. 1862. Ч. 39. 29 листопада. С. 329-332; Ч. 40. 6 грудня. С. 337-339; Ч. 41. 12 грудня. С. 346-348; Ч. 42.19 грудня. С. 353-355.

${ }^{61}$ Всячина. Там само. 1862. Ч. 39. 29 листопада. С. 336.

${ }^{62}$ ЦДІАЛ України. Ф. 362. Оп. 1. Спр. 94. Арк. 101.

${ }^{63}$ Кульшъ П. До братоิвъ на Вкраину. Вечернийъ. 1863. Ч. 2. 10 съчня. С. 9, 10.

${ }^{64}$ Кумейки. Дума (Зъ “Досвъткоิвъ” П. Кульша). Там само. 1863. Ч. 6.7 лютого. С. 41, 42.

65 Литературни въсти. Там само. Ч. 3. 17 съчня. С. 24.

${ }^{66}$ Студинський К. Галичина й Україна в листуванні 1862-1884 pp... С. IV.

67 Запросины до передплаты. Вечерницъъ. 1862. Ч. 42.19 грудня... С. 360.

${ }^{68}$ ЦДІАЛ України, Ф. 362. Оп. 1. Спр. 94. Арк. 114. К. Студинський писав: “Про яку-небудь матеріальну допомогу з України не маємо вісток, а передплатників звідтам також було небагато, бо посилка була утруднена, а “Основа” (петербурзька. - I. Р.) заступала їм краще українську культуру, як це могли вчинити “Вечерниці".

${ }^{69}$ Студинський К. До історії взаємин Галичини з Україною в рр. 1860-1873... С. 25.

${ }^{70}$ ЦДІАЛ України. Ф. 362. Оп. 1. Спр. 94. Арк. 104.

71 За те, ордъ-чого у мъстечку Воронежъ высохъ Пъшевцъвъ ставъ. Украинське оповъданье П. Кульша. Вечерницґъ. 1862. Ч. 19. 7 червня. С. 145-148; За те, що сталося съ козакомъ Бурдюгомъ на Зеленоิй недъль. Народне оповъданье П. Кульша (переведене зъ великоруського). Там само. Ч. 36.8 листопада. С. 310, 311; Ч. 37. 15 листопада. С. 319, 320; Кульшъ П. Малороссійскіе разсказы. Кіевлянинъ на 1840 годъ / издалъ М. Максимовичъ. Кіевъ, 1840. Кн. І. С. 205-215, 215-228.

72 Огняный змъй. Украинська повъсть П. Кульша. Переложивъ зъ россійського Кс. Кл. Вечерницъг. 1862. Ч. 20.14 червня. С. 155-159; Ч. 21. 21 червня. С. 170-174; Ч. 22. 28 червня. С. 185-190; Ч. 23. 5 липця.
} 


\section{Проблеми нової і новітньої історії}

передруки 3 петербурзької “Основи”, відзначивши важливість журналу, де “розкрывається правдивый образъ нашои теперьшнёи литературы”73. Передруком 3 “Основи” у “Вечерницях" 3'явилися твори П. Куліша різних жанрів: поезіі ${ }^{74}$, оповідання ${ }^{75}$, статті публіцистичного ${ }^{76}$ та $^{2}$ iсторичного ${ }^{77}$ змісту. К. Студинський аргументовано переконував, що “якби не поміч з України, якби не “Кіевлянинъ” і не “Основа”, “Вечерниці” були би упали з браку літературного, критичного і наукового матеріялу”,78. Значну частину матеріалу громада “вечерничників” почерпнула 3 Кулішевої творчості. Свою заслугу видавці “Вечерниць” справедливо вбачали у поширенні знань про Україну в Галичині. “Ледве сотній зъ читающои громады знавъ де-що про нашу ро̂дну Украину, - писалося в часописі наприкінці 1862 р., - про батька Тараса, Основяненка, Кульша, Костомарова, Марка Вовчка и т. д. Ледва девять мЂсяцЂвъ писали мы нашй "Вечерницћ”, а зъ невеличкои молодои громадки стала громада поважна..., нынъ у кождомъ закутку Галича учуемъ вже про нашу Украину ...,79.

Замість “Вечерниць”, що видавалися до червня 1863 р., у Львові з вересня того ж року почав виходити журнал "Мета" як “литературно-политичній вістникъ” під редакцією К. Климковича. "Мета” була заснована за фінансової підтримки наддніпрянських діячів, які після закриття петербурзької “Основи” в умовах посилення антиукраїнських репресій у Росії бажали перетворити новий часопис у політичний орган всього українського руху. Львівську “Мету” П. Куліш вважав “продовженням того, що почала наддніпрянська література"80. Матеріали в часописі друкувалися фонетичним правописом П. Куліша, відомим як “кулішівка”, що, на відміну від історико-етимологічного правопису М. Максимовича, яким друкували “Вечерниці”, сильніше розмежовував українську і російську мови. По суті, це стало своєрідною правописною революцією, що наблизила галичан до нової української літератури, яку видавали “кулішівкою”. Лист з України, опублікований раніше у “Вечерницях", підкреслював необхідність прийняття єдиного українського правопису: “Не знаю, якъ у васъ на Галичині, а у насъ на Вкраіні важко

С. 203-205; Ч. 24. 12 липця. С. 209-213; Ч. 25. 19 липця. С. 217-220; Ч. 26. 26 липця. С. 225-228; Огненный змъй. Повъсть П. Кульша. Кіевлянинъ / издалъ М. Максимовичъ. Кіевъ, 1841. Кн. II. С. 181-288.

${ }^{73}$ Всячина. Вечерницъъ. 1863. Ч. 5. 31 съчня. С. 40.

${ }^{74}$ Вешнякъ Т. До землячки. Основа. 1862. Лютий. С. 81, 82; Вешнякъ Т. До землячки. Вечернициг. 1863. Ч. 5.31 сьчня. С. 33; Кулішъ П. До братівъ на Вкраіну. Основа. 1862. Березіль. С. 29-32; До братоิвъ на Вкраину. Вечерницґъ. 1863. Ч. 2. 10 съчня. С. 9, 10.

75 Забоцень П. Гордовита пара (Бабусине оповідання). Основа. 1861. Ноябрь-декабрь. С. 49-56; Забоцень П. Гордовита пара (Бабусине оповьданья). Вечерницъь. 1862. Ч. 43. 28 грудня. С. 361-364; Кулишъ П. Другой человькъ. Изъ воспоминаній былого. (Посвящается Н. И. Костомарову). Основа. 1861. Февраль. С. 56-104; Иншій чоловъкъ. Оповъданье П. Кульша. Переведене зъ россійського. Вечерницгъ. 1862. Ч. 27. 2 серпня. С. 233-236; Ч. 28.9 серпня. С. 241-244; Ч. 29. 16 серпня. С. 249-252; Ч. 30.23 серпня. С. 257-261; Ч. 31.29 серпня. С. 267-270; Ч. 32. 6 вересня. С. 275-278; Ч. 33. 13 вересня. С. 282-284.

76 Хуторянинъ Листи съ хутора. Листь І. Основа. 1861. Январь. С. 310-318; Про городи й села. Вечерницъь. 1862. Ч. 28. 9 серпня. С. 246-248; Ч. 29. 16 серпня. С. 253, 254; Ч. 31.29 серпня. С. 271-272; Листи съ хутора. Листъ II. Основа. 1861. Февраль. С. 227-232; Про городи й села. Листъ II. Вечерниигғ. 1862. Ч. 31. 29 серпня. С. 271, 272; Листи съ хутора. Листь III. Основа. 1861. Марть. С. 25-32; Хуторянинъ. Чого стоить Шевченко яко поетъ народній. Вечернийг. 1862. Ч. 21. 21 червня. С. 179-182.

${ }_{77}^{77}$ Кулішъ П. Исторія Украіни одъ найдавнійшихъ часівъ. Основа. 1861. Сентябрь. С. 79-107; Исторія Украины одъ найдавньйшихъ часоิвъ (Початокъ з обширньйшого дъла П. Кулъша). Вечернищъ. 1863. Ч. 7. 14 лютого. С. 51-54; Ч. 8. 21 лютого. С. 61-63; Ч. 9.28 лютого. С. 69, 70; Ч. 10. 7 марта. С. 76-78; Ч. 11. 14 марта. С. 85, 86; Отвђтъ современной льтописи Русскаго Въстника. Основа. 1861. Февраль. С. 256-259 (ця “безіменна” стаття, на думку К. Студинського, була написана, найімовірніше, П. Кулішем, що закликав будувати літературну мову на основі народнорозмовної, переконував: “лучче своє латане, аніж чуже хапане” (див.: ЦДІАЛ України. Ф. 362. Оп. 1, Спр. 94. Арк. 108)); Якъ гадае Основа про галицьку письменность. Вечерницъг. 1862. Ч. 27. 2 серпня. С. 239, 240; Ч. 29. 16 серпня. С. 256.

${ }_{78}^{72}$ ЦІАЛ України. Ф. 362. Оп. 1. Спр. 94. Арк. 111.

${ }^{79}$ Слово до нашихъ предплатительвъ. Вечерницъь. 1862. Ч. 35.1 листопада. С. 296.

${ }^{80}$ Возняк М. Листування Панька Куліша з Олександром Кониським. Нова Україна. Місячник письменства, мистецтва, науки і громадського життя / під ред. В. Винниченка й М. Шаповала. Прага ; Берлін, 1923. Ч. 7-8. Липень-серпень. С. 274. 
читають книжки, писані Вашою правописсю. У нась усі пишуть правописсю П. Куліша ...,"1. Редакція “Мети” доклала чимало зусиль для вживання загальноукраїнського правопису.

Виданню журналу "Мета", на думку К. Студинського, передувало листовне порозуміння галицьких видавців із наддніпрянськими громадівцями, передусім П. Кулішем ${ }^{82}$. У листі до редакції "Мети” восени 1863 р., написаному з хутора Піддубень біля м. Борзни, український письменник образно звертався до "коханого побратимства" із закликом "пахати та сіяти, бо лежить наша рідна земля великим перелогом”. П. Куліш вказав адресу в Петербурзі, через яку галичанам можна було замовляти українські книжки. Він висловив щире бажання приїхати до Львова 3 дружиною Ганною Барвінок, яка “так же само серцем припадае до Вашоі братерськоі долі”, щоб ближче “подивитись на галичанську Украіну”. П. Куліш цікавився літературними здобутками галичан, запитував про нові україномовні видання та попит на них серед місцевого населення, із сарказмом висловився про польське повстання 1863 р. (“божевільні ляшки́ начинили колоту, а дурні го́лови (російські централісти. - I. P.) думають, що й наш брат хоче йти слідомъ за ними”). Із сумом говорилося, що “ніко́ли ще не було так нашому братові важко!", але “не годитця козацьким правнукам плакати" ${ }^{83}$. Однак запланована П. Кулішем поїздка в Галичину, про яку йшлося в його листі до редакції “Мети”, так і не відбулася, в 1864 р. письменник довго не міг знайти роботу ${ }^{84}$.

На сторінках "Мети” друкувалися твори П. Куліша, поряд літературними здобутками деяких інших наддніпрянців (Т. Шевченка, С. Гребінки, Марка Вовчка, Д. Мордовцева та ін.), а також галичан (В. Ільницького, В. Стебельського, О. Гороцького та ін.) і буковинця Ю. Федьковича. Так, "Мета" опублікувала три оригінальні, спеціально надіслані твори П. Куліша" “Мартин Гак", "Руїна",87, “До Щасного Саламона" 88 . У часописі були також передруковані його поезії т9 "історичний роман" "Брати”, що вийшов 1863 р. у журналі "Въстникъ ЮгоЗападной Россіи" ". Кулішеву поему "Могильні сходини” було опубліковано в "Меті" восени 1863 р. під анонімом "Гургурдядько" . Галицький читач міг ознайомитися з бібліографією книжок, що вийшли друком українською мовою в Росії, зокрема в петербурзькій “друкарні П. Куліша" . Однак, подаючи короткі відомості про розвиток "руськоі литератури у братівъ нашихъ" на Наддніпрянщині (за останні чотири роки з'явилося “стільки книжокъ руськихъ, скільки не вийшло іхъ въ цю пору въ Галичині, ні за цілихъ передущихъ 60 літъ на Вкраіні”), автор статті був змушений визнати, що галичани не мають змоги придбати видання “въ жадній львівській книгарні, ані побачити іхъ..."93.

Одночасно з “Метою”, що виходила до грудня 1865 р., народовці з січня того ж року видавали у Львові літературно-науковий часопис "Нива" під редакцією К. Горбаля. 20 номерів журналу (останній вийшов у липні 1865 р.) сприяли розвитку нової української літератури, духу національної єдності українців. Редакція "Ниви” знайомила не лише 3 творами місцевих галицьких (В. Стебельського, І. Верхратського, В. Ільницького та ін.) і буковинських (Ю. Федьковича, С. Воробкевича) письменників, але й наддніпрянсько-українських - Т. Шевченка, Марка

\footnotetext{
${ }^{81}$ Терезовській М. Зъ Украіни. Вечернииґ. 1862. Ч. 33. 13 вересня. С. 286.

${ }^{82}$ ЦДІАЛ України. Ф. 362. Оп. 1. Спр. 115. Арк. 5.

${ }^{83}$ Інститут літератури ім. Т. Шевченка НАН України. Відділ рукописних фондів і текстології, м. Київ. Ф. 3 (Франко І. Я.), Од. 3б. 4230. Арк. 153, 154; Студинський К. Слідами Куліша... С. 254, 260, 261.

${ }^{84}$ Нахлік Є. Пантелеймон Куліш... С. 212.

85 ЦДІАЛ України. Ф. 362. Оп. 1. Спр. 115. Арк. 6, 7.

${ }^{86}$ Кулішъ П. Мартинъ Гакъ. Мета. 1863. № 1 (вересень). 3 (15) жовтня. С. 35-44.

${ }^{87}$ Кулішъ П. Руіна. Там само. 1863. № 2 (жовтень). 3 (15) листопада. С. 134-148; 1864. № 5 (січень). 3 (15) серпня. С. 50-67.

88 Данило Юсъ До Счастного Саламона, прочитавши ёго “Коломийки и Шумки”. Допись зъ Украіни. Там само. 1865. № 6. 30 цвітня (12 мая). С. 173-176.

${ }^{89}$ Кулішъ П. Дума про Саву Кононенка. Там само. 1863. № 1 (вересень). С. 9-13; Сонетъ. Там само. С. 13.

${ }^{90}$ Кулішъ П. Брати Историчній романъ початку XVII віку. Там само. 1864. № 5 (січень). С. 21-45.

${ }^{91}$ Гургурдядько. Могильні сходини. Там само. 1863. № 1 (вересень). С. 18-34; № 2 (жовтень). С. $106-116$.

92 Литературні вісті. Мета. 1863. № 3 (листопадъ). С. 267, 268.

93 Там само. С. 267.
} 


\section{Проблеми нової і новітньої історії}

Вовчка, М. Старицького (псевдонім - Гетьманець), О. Стороженка та деяких ін. ${ }^{94} .3$ творів П. Куліша в "Ниві”" друкувалася без підпису історична праця "Почини лихоліття ляцького и перві козацькі бучи" в березні - травні 1865 p. ${ }^{95}$. П. Куліш присвятив свою працю козацькій сторінці в історії України, що виклика́ла особливий інтерес серед молодого покоління галицьких діячів.

У січні - квітні 1866 р. у Львові вийшло 12 номерів літературного часопису "Русалка", сама назва якого засвідчила про підтримку редакцією традицій, закладених у "Русалці Дністровій”. На відміну від своїх попередників - "Мети" і "Ниви", "Русалка" виходила етимологічним правописом, щоб знайти підтримку серед старшої частини населення, невдоволеного “кулішівкою”. Часопис часто друкував твори О. Кониського під псевдонімами, галицьких і буковинських авторів - К. Климковича, В. Шашкевича, С. Воробкевича та ін. ${ }^{96}$. Однак у "Русалці" не публікувалося жодного твору П. Куліша, працюючи як державний службовець у Варшаві 3 кінця 1864 р., він на кілька років відійшов від активної публіцистичної і літературної діяльності, практично не мав зв'язків з Галичиною. У повному переліку Кулішевих праць з 1862 р. (початок виходу “Вечерниць”) до 1865 р. включно міститься 72 позиції, з них 24 або третина це видання в Галичині, насамперед народовські (12 - у “Вечерницях", сім - у "Меті”, одна - в "Ниві”) ${ }^{97}$ та кілька - русофільських (три - у “Слові” та одна - в збірнику “Галичанинъ” (далі “Галичанин”) 1861 р. вийшов у “Слові” Кулішевий вірш “З-за Дунаю”. Левова частка галицьких публікацій побачила світ в 1862 р. (11) та 1863 р. (9), тоді як у 1864 і 1865 рр. - по дві, а в 1866 р. - жодної (П. Куліш мав того року лише одну анонімну публікацію у Варшаві) ${ }^{98}$.

Крім галицьких народовців, П. Куліш у першій половині 1860 -х рр. мав контакти з русофілами (москвофілами), що вважали русинів Галичини частиною більш широкої східнослов'янської, панруської спільноти, яку означувано поняттям “русскій” народ. Цей термін не означав російський (великоруський, московський), бо в тій спільноті визнавалося існування також “малоруського" масиву. В особі русофілів національний рух у Галичині отримав специфічний варіант "малоросійського" патріотизму, для якого була характерна відданість "Малій Русі", iï історії та особливій мовній традиції. В австрійський період русофільська течія, що панруські (в політичній площині - проросійські) симпатії поєднувала 3 демонстративним австрійським лоялізмом, пройшла складну ідейну еволюцію ${ }^{99}$. Русофіли видавали 3 січня 1861 р. газету “Слово” у Львові під редакцією Б. Дідицького (до 1870 р.), що в перші роки існування намагалася виступати від імені русинів Галичини, незалежно від їх політичної орієнтації. У питаннях національної ідентичності газета до другої половини 1860 -х рр. дотримувалася, по суті, “проукраїнських" позицій ${ }^{100}$.

“Слово” відіграло важливу роль у поширенні в Галичині культу Т. Шевченка, що було чинником формування української національної самосвідомості серед місцевих русинів. Так, редакція надрукувала короткий життєпис Т. Шевченка - "великого украино-руского поета", де згадувалося про публікацію "надгробного" слова П. Куліша передруком 3 петербурзької “Основи”, вміщеного раніше у “Вечерницях" 1862 р. (ч. 22) ${ }^{101}$. У часописі неодноразово містилася інформація, що в книгарні русофільського Ставропігійського Інституту у Львові продавалися видані в Парижі та Петербурзі портрети українських письменників і вчених, у т. ч.

\footnotetext{
${ }^{94}$ ЦДІАЛ України. Ф. 362. Оп. 1. Спр. 74. Арк. 60; Студинський К. До історії взаємин Галичини 3 Україною в рр. 1860-1873. С. 27.

95 Куліш П. Почини лихоліття ляцького и перві козацькі бучи (Историчня вивідка). Нива. 1865. № 9. 30 марта. С. 141, 142; № 10. 10 цвітня. С. 157-159; № 11. 20 цвітня. С. 174-176; № 12.30 цвітня. С. 189-191; № 13. 10 мая. С. 205-207; № 14. 20 мая. С. 221-223.

${ }^{96}$ ЦДІАЛ України. Ф. 362. Оп. 1. Спр. 74. Арк. 60; Спр. 117. Арк. 30, 31.

${ }^{97}$ Кирилюк С. Бібліографія праць П. О. Куліша та писань про нього. Київ, 1929. С. 36, 38, 39, 40, 41.

${ }^{98}$ Кравченко О. "Бібліографія праць П. О. Куліша та писань про нього” Є. Кирилюка у контексті сучасних наукових досліджень. Історико-педагогічний альманах. Умань, 2008. Вип. 2. С. 82, 83, 84.

${ }^{99}$ Вендлянд А.-В. Русофіли Галичини. Українські консерватори між Австрією та Росією, 1848-1915 / пер. 3 нім. Х. Назаркевич. Львів, 2015. С. 619.

${ }^{100}$ Сухий О. Від русофільства до москвофільства (російський чинник у громадській думці та суспільнополітичному житті галицьких українців у XIX столітті). Львів, 2003. С. 106.

${ }^{101}$ Коротка житьепись Тараса Шевченка. Слово. 1862. Ч. 53. 7 (19) юлія. С. 207-209.
} 
П. Куліша, як і “великого пъвца Украины” Т. Шевченка, М. Костомарова, І. Котляревського, Г. Квітки-Основ'яненка, Є. Гребінки, Марка Вовчка та ін., із закликом їх придбати ${ }^{102}$. За цих умов П. Куліш у першій половині $1860-\mathrm{x}$ рр. встановив зв'язки в Галичині як з народовськими, так і з русофільськими діячами.

П. Куліш надіслав редакції “Слова” програму петербурзької “Основи”, яку вона передрукувала влітку 1861 р., із запрошенням галичан до передплати журналу ${ }^{103}$. Редактор Б. Дідицький отримав від П. Куліша твори нової української літератури, що вийшли друком у його петербурзькій друкарні, серед яких були власні видання й упорядковані ним збірники ${ }^{104}$. "Слово" помістило про ці книжки в липні 1861 р. прихильну звістку: "Украинска словесность движется значительно впередъ”. Позитивно оцінювалася діяльність самого П. Куліша, що літературу з власної друкарні поширював “по всей Украинь”, було вказано адресу, де можна було придбати видання ${ }^{105}$. Б. Дідицький передрукував "переднє слово" до опублікованого в Петербурзі 1861 р. історичного оповідання "Хмельнищина", що містило короткий проспект подальшої видавничої діяльності ${ }^{106}$. У “Слові” писалося про плани П. Куліша видати найближчим часом невеликі книжки про гетьманів I. Виговського, І. Брюховецького, П. Дорошенка, I. Мазепу, К. Розумовського, полковника I. Поповича, які “поможуть усякому ... исторію Украины зрозумъти и багато де-чого зъ неи навчитися" 107 .

Отримавши кращі зразки нової української літератури, Б. Дідицький сподівався на співпрацю з П. Кулішем, що знайшла відгук у публікаціях у петербурзькій “Основі” та львівському "Слові" 108. Так, на сторінках "Основи" в лютому 1861 р. опубліковано польськомовну поезію Б. Дідицького “Нема Русі!”, без вказівки автора, та ії переклад на російську мову ${ }^{109}$. Редакція журналу надрукувала коментар М. Костомарова, що за публікацію вірша “будуть благодарны 3 милліона Русиновъ”, бо усвідомлення “единства Червоно-русской Земли сь остальною Русью не исчезло и до настоящаго времени, не смотря на всь иноплеменныя усилія" У вересневому журналі “Основа” 1861 р. була опублікована поезія П. Куліша “З-за Дунаю”, яку невдовзі передрукувало "Слово"111. Вірш українського письменника мав резонанс у Галичині, редакція "Слова" опублікувала на нього дві віршовані відповіді - I. Гушалевича і Галичанина (псевдонім Я. Головацького) ${ }^{112}$. Галичани сприйняли поезію “З-за Дунаю”, написану за кордоном перед поверненням П. Куліша в Україну 1861 р., як фольклоризоване ліричне самовираження, звернене до всіх співвітчизників-однодумців. У відповідь на Кулішеві слова "Покину, покину Чужую чужину Та на Украину Соколомъ полыну” І. Гушалевич писав:

$$
\begin{aligned}
& \text { Ой лети соколе / Та на Украину } \\
& \text { А } 3 \text { оิттамъ къ Бескиду / По-надъ Галичину }{ }^{113} \text {. }
\end{aligned}
$$

Всеукраїнську національну єдність галичан і наддніпрянців по обидва боки Збруча обстоювала поезія Галичанина:

\footnotetext{
102 Див.: Новинки. Слово. 1862. Ч. 91.17 (29) ноемврія. С. 356; Новинки. Там само. 1863. Ч. 33.27 апрьля (9 мая). С. 134; Новинки. Там само. Ч. 54. 10 (22) юлія. С. 216.

${ }^{103}$ Новинки. Там само. 1861. Ч. 43. 28 юнія (10 юлія). С. 252.

${ }^{104}$ ЦДІАЛ України. Ф. 362. ОП. 1. Спр. 74. Арк. 42.

105 Новинки. Слово. 1861. Ч. 44.1 (13) юлія... С. 256.

106 Студинський К. До історії взаємин Галичини з Україною в рp. 1860-1873... С. 16.

107 Литературное извъстіе. Слово. 1861. Ч. 47.12 (24) юлія... С. 268.

108 Студинський К. До історії взаємин Галичини з Україною в рр. 1860-1873 ... С. 16, 17.

109 Костомаровъ Н. Отвђтъ на выходки газеты (краковской) “Сzas" и журнала "Revue contemporaine". Основа. 1861. Февраль. С. 121-135. Вірш "Niema Rusi! Odpowiedż na plakaty Polaków w Uniwersytecie we Lwowie 1860 r.”. C. 122-126.

${ }^{110}$ Костомаровъ Н. Отвђтъ на выходки ... Основа. 1861. Февраль. С. 127.

111 Кулішъ П. 3 за Дунаю. Основа. 1861. Сентябрь. С. 33, 34; Кулишъ П. Зъ-за Дунаю. Слово. 1861. Ч. 71. 4 (16) октобрія. С. 366.

${ }_{112}$ Студинський К. До історії взаємин Галичини з Україною в рp. 1860-1873 ... С. 16.

113 Гушалевичъ И. Отвътъ зъ подъ Бискида на голосъ “Зъ-за Дунаю”. Слово. 1861. Ч. 76.21 октобрія (2 новембрія). С. 388.
} 


\section{Проблеми нової і новітньої історії}

Коли ймешь кидати / Чужую чужину

Соколомъ вертати / В роिдну Украину;

Не минай родины / Старой Галичины.

Вступи милый брате / До нашои хаты! ${ }^{114}$.

Обидві відповіді галицьких письменників передрукувала “Основа” в січні 1862 p. ${ }^{115}, 3$ приміткою редакції, автором якої, за припущенням К. Студинського, міг бути В. Білозерський ${ }^{116}$. У примітці говорилося про “дорогихъ и близкихъ намъ Галичанъ”, “нашихъ братьевъ”, що на сторінках часопису “Слово" привітно відгукнулися на вірш П. Куліша ${ }^{117}$. Зворушливі поетичні відгуки галичан сподобалися П. Кулішеві, який у листі до О. Кониського в кінці 1861 р. зауважив, що у львівському “Слові” “по-нашому наламуються писати”. Мабуть, са́ме П. Куліш залучив його до надсилання власних матеріалів для публікацій у “Слові”. Газета в 1862-1863 рр. надрукувала 14 дописів О. Кониського з Полтави ${ }^{118}$. Незадоволений цензурними умовами в Російській імперії і редагуванням петербурзької “Основи”, П. Куліш уже на початку 1860-х рр. усвідомлював важливе значення галицької періодики як трибуни для українських письменників ${ }^{119}$.

Отримавши від П. Куліша журнал “Основа” зі статтею М. Костомарова, опублікованою в лютому 1861 р., Б. Дідицький передрукував матеріал на сторінках "Слова" вірша "Niema Rusi!" Б. Дідицького ${ }^{121}$. Стаття підкреслювала нерозривну єдність Галичини 3 усім руським світом, відмінність між двома руськими (“южно-“і “велико-русскимъ”) народами, а також окремішність Південної Русі від Польщі. Зокрема, М. Костомаров писав, що "южнорусскій народъ - не Поляки", Червона Русь, тобто Галичина, була насильно приєднана до Польщі, захоплення “совершилось съ кровопролитіями...” ${ }^{22}$. На початку передрукованої статті М. Костомарова містилася редакційна примітка, що висловлені автором думки збігаються "съ общимъ мнъніемъ нашой Галицкой Руси”, читаючи ю, мимовольно думаешъ, будто она писана для “Слова" 123 . Літературний збірник "Галичанинъ” у Львові русофільського спрямування, публікуючи бібліографію М. Костомарова в 1863 p. ${ }^{124}$, зауважив, що він був "родом украинецъ”, разом з Т. Шевченком і П. Кулішем, становить “троезвђздіе, що яркимъ свђтломъ знанія и волъ сіяе нынъ для всей Малой Руси"

У 1861-1862 рр. твори П. Куліша тричі публікувалися у львівській газеті “Слово” (у т. ч. один передрук з “Основи”), редактор якої - Б. Дідицький, як відомо, на перших порах прихильно ставився до українського руху, співпраці з наддніпрянськими діячами. Кулішеві дописи у “Слові”, за словами К. Студинського, закликали до “єднання Галичини з Україною"126. Так, П. Куліш писав, що на Наддніпрянщині “теперь иде велике змагання за нашу, спільню зъ

\footnotetext{
${ }^{114}$ Галичанинъ. Братови зъ-за Дунаю. Там само.

${ }^{115}$ Голосъ Галичанъ. І. Отвітъ зъ-подъ Бискида на голосъ “Зъ-за Дунаю”. ІІ. Братові зъ-за Дунаю. Основа. 1862. Січень. С. 109, 110.

${ }_{116}$ ЦДІАЛ України. Ф. 362. Оп. 1. Спр. 101. Арк. 10, 11.

${ }^{117}$ Современная южнорусская льтопись. Основа. 1862. Січень. С. 109.

118 Студинський К. Зв'язки Олександра Кониського з Галичиною в рр. 1862-1866. Записки НТШ. Львів, 1929. T. CL. C. $273,288$.

${ }^{119}$ Нахлік Є. Пантелеймон Куліш... С. 202, 203.

120 Костомаровъ Н. Отвђтъ на выходки газеты (краковской) "Сzas" и журнала "Revue contemporaine". Основа. 1861. Февраль. С. 121-135; Отвظтъ Костомарова на нькоторыи лжеученія журналистовь польскихъ. Слово. 1861. Ч. 67. 20 септемврія (2 октобрія). С. 349, 350; Ч. 68. 23 септемврія (5 октобрія). С. 353, 354; Ч. 69.27 септемврія (9 октобрія). С. 357,358 ; Ч. 70.30 септемврія (12 октобрія). С. 361, 362.

${ }^{121}$ ЦДІАЛ України. Ф. 362. Оп. 1. Спр. 74. Арк. 44.

${ }^{122}$ Костомаровъ Н. Отвظтъ на выходки ... Основа. 1861. Февраль. С. 132.

${ }^{123}$ ОтвЂть Костомарова ... Слово. 1861. Ч. 67.20 септемврія (2 октобрія). С. 349.

${ }^{124}$ Сочиненія и изданія Николая Ивановича Костомарова. Галичанинъ. Литературный сборникъ. Львовъ, 1863. Кн. І. Вып. ІІ. С. 161-163.

${ }^{125}$ Сочиненія и изданія Николая Ивановича Костомарова. Галичанинъ. Литературный сборникъ. Львовъ, 1863. Кн. І. Вып. II. С. 161.

${ }^{126}$ Студинський К. Слідами Куліша... С. 244.
} 
вашою словесность”. “Заспівае нашъ братъ за Дунаемъ або підъ Полтавою, - наголошував він, - а въ ві Львові і въ Бескидахъ голосъ лунае. Застогне Галицька Русь підъ Карпатами, а по надъ Дніпромъ у людей серце болить" " І собі”, написана за мотивами української народної пісні ${ }^{128}$. П. Куліш українським фонетичним правописом у поетичній формі передав красу живої народнорозмовної мови.

Як і народовські видання, русофільське “Слово” передруковувало твори українських авторів 3 петербурзького журналу “Основа”. К. Студинський зауважив, що “Основа” В. Білозерського і творчість наддніпрянських письменників були для львівського “Слова” “скарбницею наукового і літературного знання" 29 . У кількох номерах газети повторно публікувалася науково-публіцистична стаття П. Куліша "Полякамъ объ Украинцахъ"130. "Я польское и $я$ украинское разошлись, въ теченіе въковъ, - писав П. Куліш, - на такое разстояніе, что Полякъ, при всемъ стараніи, не можетъ войти въ натуру Украинца, а Украинецъ, при всьхъ приманкахъ, войти въ натуру польскую не хочетъ" "131. Редакція “Слова” декларувала прихильне ставлення до народовських часописів, зокрема привітала початок видання “Мети” у Львові 1863 р., де поряд iз галицькими письменниками будуть міститися твори “братей-Украинце̂въ”. П. Куліш, “славнЊйшій ихъ писатель”, листовно повідомив про це редактора К. Климковича, пообіцявши, що “до кождого выпуска его “Меты” присылати буде утворы свого пера”. На думку видавців “Слова”, "Мета” як друкований орган “закордоньскои Руси” давав уявлення про життя-буття “другои болльой половины руского міра ...,"132.

У літературному збірнику "Галичанинъ” на початку 1860-х рр. вийшла друком поезія П. Куліша "Кінець Дунайськоі Думи"133, поряд 3 творами М. Костомарова, Д. Мордовцева, О. Кониського та ін. У примітці русофільської редакції в 1863 р. наголошувалося, що перша половина Кулішевої поезії побачила світ у петербурзькій “Основі”, а друга - друкується вперше "по рукописи самого жъ автора, на желанье которого и правопись его ненарушимо ту задержана"134. 3 любов”ю до України автор емоційно писав: “Тихо Дунай, тихо / Жовті піски миє. / Якъ згадаю Украіну - / Серденько заниє""135.

Перші Кулішеві контакти з Галичиною закінчилися, коли він восени 1864 р. виїхав на державну службу до Варшави, де працював чиновником Установчого комітету в Царстві Польському. П. Куліш намагався поліпшити скрутне матеріальне становище, а в ідейному плані поєднати український патріотизм із лояльністю до російського царизму, що після придушення Січневого повстання 1863 р. став на боротьбу проти польського визвольного руху. Щоправда, таке роздвоєння було для П. Куліша обтяжливим, викликало критику серед наддніпрянських громадівців і завершилося його відставкою в 1868 р. Кулішевому авторитетові серед галицьких народовців варшавська служба серйозно не зашкодила, але його безпосередні зв'язки 3 краєм перервалися $^{136}$. П. Куліш відновив листування з Я. Головацьким у лютому 1866 р., а суперечки навколо публікації Кулішевих листів, що розгорілися в галицькій пресі в 1866-1867 рр., мали відгук навіть у російській періодиці, засвідчили поглиблення розходжень у національному русі в краї на дві орієнтації - народовську і русофільську (москвофільську). Розірвавши стосунки 3

\footnotetext{
${ }^{127}$ Кулішъ П. Голосъ зъ Украіни. Слово. 1863. Ч. 68. 28 августа (9 септембрія). С. 270.

${ }^{128}$ Кулішъ П. Самъ собі (Правописію украиньскою). Там само. 1862. Ч. 7. 24 януарія (5 февруарія). С. 26.

129 ЦДІАЛ України. Ф. 362. Оп. 1. Спр. 97. Арк. 45.

${ }^{130}$ Кулишъ П. Полякамъ объ Украинцахъ. Основа. 1862. Лютий. С. 67-86. Передрук: Полякамъ объ украинцахъ (Статья П. Кулиша, вынята изъ “Основы” ІІ книжки за 1862 г.). Слово. 1862. Ч. 80-83. 10 (22) октобрія - 20 октобрія (1 ноеврія).

131 Кулишъ П. Полякамъ объ Украинцахъ. Основа. 1862. Лютий. С. 75.

132 Новинки. Слово. 1863. Ч. 55.13 (25) юлія... С. 220.

133 Кулишъ П. Кінець Дунайськоі Думи. Галичанинъ. Литературный сборникъ. Львовъ, 1863. Кн. I. Вып. II. С. 7, 8.

${ }^{134}$ Там само. С. 7.

135 Там само. С. 8.

${ }^{136}$ Нахлік С. Пантелеймон Куліш... С. 220, 234, 244.
} 


\title{
Проблеми нової і новітньої історії
}

Я. Головацьким і русофілами, П. Куліш зосередився на підтримці народовців та їхнього журналу "Правда" у Львові, що стало предметом окремого дослідження ${ }^{137}$.

Таким чином, серед наддніпрянських діячів П. Куліш мав найбільший вплив на розвиток українського руху в Галичині 1860-х - початку 70-х рр., встановив зв'язки 3 краєм після першої поїздки до Львова влітку 1858 р. Він кілька років листувався з Я. Головацьким, з яким познайомився в столиці Галичини, мав контакти з лідерами народовців Д. Танячкевичем і К. Климковичем, русофілом Б. Дідицьким та ін. П. Куліш відіграв особливу роль в утвердженні української національної ідеї в краї, підтримав діяльність галицьких народовців на початку 1860-х рр. Різножанрові твори П. Куліша - поезії, оповідання, наукові і публіцистичні статті тощо - друкувалися на сторінках часописів "ранніх" народовців у Львові “Вечерниці” (1862-1863рp.), "Мета" (1863-1865 рр.) і “Нива” (1865 р.). Це були нові й раніше опубліковані праці, насамперед, 3 альманаху “Киевлянин” (1840 і 1841 рр.) та петербурзького журналу “Основа” (1861-1862рp.). К. Студинський висловив думку, що в "pp. 1862-66 приходили через руки Куліша грошеві підмоги для галицьких видань" ${ }^{\text {"138, }}$, але цю тезу не вдалося підтвердити документально.

Водночас П. Куліш на початку 1860-х рр. друкувався в русофільських виданнях - газеті “Слово” і літературному збірнику “Галичанин”, що проявляли інтерес до нової української літератури, прихильно ставилися до співпраці з наддніпрянськими діячами. Загалом у галицькій пресі з 1861 до 1865 рр. включно вийшло в світ 24 публікації П. Куліша, переважно у виданнях народовців, та брошура з оповіданням “Дівоче серце” у Львові 1862 р., передрукована 3 "Вечерниць". Взаємини між П. Кулішем і галицькими діячами, по суті, перервалися після його переходу на державну службу до Варшави восени 1864 р. та в умовах посилення антиукраїнських репресій у Російській імперії та внутрішньої кризи в діяльності "ранніх" народовців. У 1865 р. в Галичині вийшли друком лише два твори П. Куліша в часописах "Мета" і “Нива", а в 1866 р. - жодного. Кулішевий інтерес до Галичини проявився на початку 1866 р., коли він відновив листування з Я. Головацьким, був втягнутий у дискусії між галицькими народовцями i русофілами. П. Куліш дав сильний поштовх для діяльності галицьких народовців через надсилання творів нової української літератури для ознайомлення і публікації в пресі, заклики до духовно-культурного єднання галичан з Україною.

\section{THE FIRST CONTACTS OF PANTELEIMON KULISH WITH GALICIA (1858-1865)}

\author{
Ihor RAIKIVSKYI \\ State Higher Educational Institution \\ "Vasyl' Stefanyk Precarpathian National University", \\ Department of History of Ukraine and methods of teaching history, \\ Taras Shevchenko st., 57, 76000, Ivano-Frankivsk, Ukraine \\ e-mail:i.ray@ukr.net
}

\begin{abstract}
Summary
The article covers Panteleimon Kulish's contacts with Galicia - from his first visit to Lviv in the summer of 1858 and to his transfer to the civil service at the end of 1864 and the appearance of the last publications in the magazines of the "early"populists of 1865. P. Kulish played a special role in the establishment of Ukrainian national identity among Galicians, especially in 1867 - early 1870's and supported the activities of local populists. Considerable attention was paid to P. Kulish's correspondence with Ya. Holovatskyi after acquaintance in 1858, relations with the leaders of the populists D. Tanyachkevych and K. Klymkovych, Russophile B. Didytskyi and others. Various genre works by P. Kulish - both new and previously published, primarily from the almanac "Kievlianin" of 1840 and 1841 and the St. Petersburg magazine "Osnova"(1861-1862) - were regularly published in the populists' press in Lviv - magazines "Vechernytsia"(1862-1863), "Meta"(1863-1865) and "Nyva"(1865). At the same time, P. Kulish's works were published in Russophile (Moscvophile) publications - the newspaper "Slovo" and the literary collection "Halychanyn", which, like the populists, in the early
\end{abstract}

137 Райківський І. Внесок Пантелеймона Куліша у видання львівського журналу “Правда” (1867 - початок 1870-х років)... С. 69-82.

${ }^{138}$ Студинський К. До історії взаємин Галичини з Україною в рp. 1860-1873 ... С. 29. 


\section{Галичина}

1860 's showed interest in the new Ukrainian literature, the national movement in sub-Russian Ukraine. In the Galician press from 1861 to 1865 inclusive, 24 publications by P. Kulish were published, in the absolute majority in the publications of the populists, and a brochure with the story "Maiden's Heart"in Lviv in 1862, reprinted from "Vechernytsia". Kulish's ties with Galician figures were severed after his appointment as a Russian official in Warsaw amid intensified anti-Ukrainian repression by Russian tsarism under the Valuev Circular of 1863 and an internal crisis in the activities of "early"populists. P. Kulish had the greatest influence among Ukrainian figures on the development of the national movement in Galicia in the 1860's, was a promoter of the idea of national unity of Ukraine. P. Kulish's interest in Galicia manifested itself with new force in 1866, but this issue became the subject of a separate study.

Keywords: Panteleimon Kulish, Ukrainian figure, Galicia, contacts, magazine, populists, russophiles.

\section{REFERENCES}

Barvinskyi, O. (2004). Spomyny z moho zhyttia [Memories from My Life]. Chast. I-II. A. Shatska, O. Fedoruk (Uporiad.). L. Vynar, I. Hyrych (Ed.). Niu-York; Kyiv (in Ukrainian).

Barvinskyi, O. (2009). Spomyny z moho zhyttia [Memories from My Life]. Vol. II, chast. III ta IV.

A. Shatska (Uporiad.); B. Yanyshyna (Comp.); L. Vynar, M. Zhulynskyi (Ed.). Niu-York; Kyiv (in Ukrainian).

Central State Historical Archives of Ukraine in Lviv (TsDIAL of Ukraine). F. 309 (NTSh. m. Lviv).

Op. 1. Spr. 2296. 7 p.

TsDIAL of Ukraine. F. 362 (Studynskyi K. - akademik). Op. 1. Spr. 74.88 p.

TsDIAL of Ukraine. F. 362. Op. 1. Spr. 94.202 p.

TsDIAL of Ukraine. F. 362. Op. 1. Spr. 97.85 p.

TsDIAL of Ukraine. F. 362. Op. 1. Spr. 101. 43 p.

TsDIAL of Ukraine. F. 362. Op. 1. Spr. 115. 138 p.

TsDIAL of Ukraine. F. 362. Op. 1. Spr. 141. 106 p.

Chastyna lystu vysokopovazhnoho professora vi Lvovskimъ universyteti Yakova Fedorovycha Holovatskoho do redaktora (30-ho sichnia 1862 r.) [Part of a Letter from Yakiv Fedorovych Holovatsky, a Highly Respected Professor at the University of Lviv, to the Editor (January 30, 1862)]. (1862). Osnova. Lypets' (iiul'), pp. 68-72 (in Ukrainian)

Danylo Yus. (1865). Do Schastnoho Salamona, prochytavshy joho "Kolomyiky y Shumky”. Dopys z Ukrainy [To Happy Solomon, having read his "Kolomyiky and Shumky". Letter from Ukraine]. Meta, no. 6, 30 tsvitnia (12 maia), pp. 173-176 (in Ukrainian).

Dei, O. I. (1969). Slovnyk ukrainskykh psevdonimiv ta kryptonimiv (XVI-XX st.) [Dictionary of Ukrainian Pseudonyms and Cryptonyms (16th-20th centuries)]. Kyiv (in Ukrainian).

Divoche sertse. Idyliia P. Kulisha [Maiden's Heart. Idyll of P. Kulish]. (1862). Vechernytsi, ch. 39, 29 lystopada, pp. 329-332; ch. 40, 6 hrudnia, pp. 337-339; ch. 41, 12 hrudnia, pp. 346-348; ch. 42, 19 hrudnia, pp. 353-355 (in Ukrainian). Ukrainian).

Doroshenko, D. (without a year). Panteleimon Kulish [Panteleimon Kulish]. Kyiv; Liaiptsih (in

Franko, I. (1981). Pysannia I. P. Kotliarevskoho v Halychyni [Writtings of I. P. Kotliarevskyi in Galicia]. Zibr. tvoriv u 50-ty t. Kyiv, vol. 31, pp. 321-334 (in Ukrainian). Ukrainian).

Franko, I. (1984). Ukraintsi [Ukrainians]. Zibr. tvoriv in 50 vol. Kyiv, vol. 41, pp. 162-193 (in

Halychanyn. Bratovy z-za Dunaiu [To Brother from across the Danube]. (1861). Slovo, ch. 76, 21 oktobriia (2 novembriia), pp. 388 (in Ukrainian).

Holos Halychan. I. Otvitъ z-pod Byskyda na holos "Z-za Dunaiu”. II. Bratovi z-za Dunaiu [The Voice of Galicians. I. Answer from under the Beskids to the Voice "From Across the Danube". II. To Brother from across the Danube]. (1862). Osnova. Sichen, pp. 109, 110 (in Ukrainian).

Hordynskyi, Ya. (1917). Do istorii kulturnoho y politychnoho zhytia v Halychyni u 60-kh rr. XIX v. [To the History of Cultural and Political Life in Galicia in the 60s of the 19th Century]. Zbirnyk filolohichnoi sektsii NTSh. Lviv, vol. XVI (in Ukrainian).

Hurhurdiadko. (1863). Mohylni skhodyny [Grave meetings]. Meta, no. 1 (veresen'), pp. 18-34; no. 2 (zhovten'), pp. 106-116 (in Ukrainian).

Hushalevych, Y. (1861). Otvit z pod Byskyda na holos “Z-za Dunaiu” [Answer from under the Beskids to the Voice "From Across the Danube"]. Slovo, ch. 76, 21 oktobriia (2 novembriia), pp. 388 (in Ukrainian).

Institute of Manuscript of V. I. Vernadsky National Library of Ukraine. F. 10 (Arkhiv VUAN). Od. zb. 17270.10 p. (in Ukrainian).

Khutorianyn Lysty s khutora. Lyst I [Letters from the Hamlet. Letter I]. (1861, Yanvar'). Osnova, pp. 310-318 (in Ukrainian). 


\section{Проблеми нової і новітньої історії}

Ukrainian).

Lysty s khutora. Lyst II [Letters from the Hamlet. Letter II]. (1861, Fevral'). Osnova, pp. 227-232 (in Ukrainian).

Lysty s khutora. Lyst III. [Letters from the Hamlet. Letter III]. (1861, Mart.). Osnova, pp. 25-32 (in

Khutorianyn. Choho stoit Shevchenko yako poet narodnii [What is Shevchenko Worth as a Folk Poet]. (1862, 21 chervnia). Vechernytsi, ch. 21, pp. 179-182 (in Ukrainian).

Korduba, M. (1928). Zviazky V. Antonovycha z Halychynoiu [V. Antonovych's Connections with Galicia]. Ukraina. Naukovyi dvokhmisiachnyk ukrainoznavstva. Kyiv, kn. 5, pp. 33-78 (in Ukrainian).

Korespondentsyia Yakova Holovatskoho v litakh 1850-62 [Correspondence of Yakiv Holovatsky in the Years 1850-62] (1905). K. Studynskyi (Vydav.). Zbirnyk filolohichnoi sektsyi NTSh. Lviv, vol. VIII, ch. 290 (in Ukrainian).

Korotka zhytepys' Tarasa Shevchenka [A Short Biography of Taras Shevchenko]. (1862). Slovo, ch. 53, no. 7 (19) yuliia, pp. 207-209 [in Ukrainian].

Kostomarov, N. Otvet na vykhodky hazety (krakovskoi) "Czas"y zhurnala "Revue contemporaine" [The Answer to the Antics of the Newspaper (Cracow) "Czas" and the Magazine "Revue Contemporaine"]. (1861, Fevral'). Osnova, pp. 121-135 (in Russian).

Kravchenko, O. (2008). "Bibliohrafiia prats P. O. Kulisha ta pysan pro noho" Ye. Kyryliuka u konteksti suchasnykh naukovykh doslidzhen' ["Bibliography of works by P. O. Kulish and writings about him" by Ye. Kyryliuk in the context of modern scientific research]. Istoryko-pedahohichnyi almanakh. Uman, iss. 2, pp. 82-94 (in Ukrainian).

Kulish, P. (1864). Braty. Istorychnii roman pochatku XVII viku [Brothers. Historical novel of the early XVII century]. Meta, no. 5 (sichen'), pp. 21-45 (in Ukrainian).

Kulish, P. (1863, 10 sichnia.). Do brativ na Vkrainu [To the Brothers of Ukraine]. Vechernytsi, ch. 2, pp. 9,10 (in Ukrainian).

Kulish, P. (1861, Fevral'). Druhoi chelovek. Iz vospomynanii byloho. (Posviashchaetsia N. Y. Kostomarovu) [Another Person. From the Memories of the Past. (Dedicated to N. I. Kostomarov)]. Osnova, pp. 56-104 (in Russian).

Kulish, P. (1863). Duma pro Savu Kononenka [Duma about Sava Kononenko]. Meta, no. 1 (veresen'), pp. 9-13 (in Ukrainian).

Kulish, P. (1863, 28 avhusta (9 septembriia)). Holos z Ukrainy [Voices for Ukraine]. Slovo, ch. 68, p. 270 (in Ukrainian).

Kulish, P. (1861, Sentiabr'). Istoriia Ukrainy od naidavniishykh chasiv [History of Ukraine From the Earliest Times]. Osnova, pp. 79-107 (in Ukrainian).

Kulish, P. (1840). Malorossiiskie razskazy [Little Russian Stories]. Kievlianyn na 1840 hod. M. Maksymovych (publisher). Kiev, kn. I, pp. 205-215, 215-228 (in Russian). Ukrainian).

Kulish, P. (1863). Martyn Hak [Martyn Hak]. Meta, no. 1 (veresen'), 3 (15) zhovtnia, pp. 35-44 (in

Kulish, P. (1865). Pochyny lykholittia liatskoho y pervi kozatski buchy (Ystorychnia vyvidka) [The beginning of the Polish bad times and the first Cossack noises (Historical intelligence)]. Nyva, no. 9, 30 marta, pp. 141, 142; no. 10. 10 tsvitnia. pp. 157-159; no. 11, 20 tsvitnia, pp. 174-176; no. 12, 30 tsvitnia, pp. 189-191; no. 13, 10 maia, pp. 205-207; no. 14, 20 maia, pp. 221-223 (in Ukrainian).

Kulish, P. (1863). Ruina [The Ruin]. Meta, no. 2 (zhovten'), 3 (15) lystopada, pp. 134-148; 1864, no. 5 (sichen'), 3 (15) serpnia, pp. 50-67 (in Ukrainian).

Kulish, P. (1862). Sam sobi (Pravopysiiu ukraynskoiu) [Himself (Spelling in Ukrainian)]. Slovo, ch. 7, 24 yanuariia (5 fevruariia), p. 26 (in Ukrainian).

Kulish, P. (1863). Sonet [The sonnet]. Meta. № 1 (veresen'), p. 13 (in Ukrainian).

Kulish, P. (1862). Vsiachyna [Everything]. Vechernytsi, ch. 39, 29 lystopada, p. 336 (in Ukrainian).

Kulish, P. (1861, Sentiabr'). Z-za Dunaiu [Beyond the Danube]. Osnova, p. 33, 34 (in Ukrainian). Ukrainian).

Kulish, P. (1861). Z-za Dunaiu [Beyond the Danube]. Slovo. ch. 71, 4 (16) oktobriia, p. 366 (in

Kulysh, P. (1863). Kinets Dunaiskoi Dumy [The End of the Danube Duma]. Halychanyn. Lyteraturnyi sbornyk, yzdavaemyi Ya. O. Holovatskym y B. A. Didytskym. Lvov, kn. I, iss. II. pp. 7, 8 (in Ukrainian). (in Russian).

Kulysh, P. (1862, liutyi). Poliakam ob Ukrayntsakh [For Poles about Ukrainians]. Osnova, pp. 67-86

Kumeiky. (1863) Duma (Z "Dosvitkiv" P. Kulisha) [Kumeiki. Duma (For "Dosvetky”by P. Kulish)]. Vechernytsi, ch. 6, 7 liutoho, pp. 41, 42 (in Ukrainian).

Kyryliuk, Ye. (1929). Bibliohrafiia prats P. O. Kulisha ta pysan pro noho [Bibliography of works by P. O. Kulish and writings about him]. Kyiv (in Ukrainian). 


\section{Галичина}

Lyteraturni visti [Literary News]. (1863). Meta, no. 3 (lystopad), pp. 267, 268 (in Ukrainian).

Lyteraturnoe yzvestie [Literary News]. (1861). Slovo, ch. 47, 12 (24) yuliia, p. 268 (in Ukrainian).

Lyteraturny visty [Literary News]. (1863). Vechernytsi, ch. 3, 17 sichnia, p. 24 (in Ukrainian).

Mudryi, M. (2002). Natsionalno-politychni oriientatsii v ukrainskomu suspilstvi Halychyny avstriiskoho periodu u vysvitlenni suchasnoi istoriohrafii [National and Political Orientations in Ukrainian Society of Galicia (the End of the $18^{\text {th }}$ - the beginning of the $20^{\text {th }}$ centuries]. Visnyk Lvivskoho universytetu. Seriia istorychna. Lviv, iss. 37, ch. 1, pp. 465-500 (in Ukrainian).

Mudryi, M. (2003). Formuvannia novochasnoi natsionalno-politychnoi kultury ukrainskoho suspilstva Halychyny (problema zovnishnikh modelei) [Forming the Modern National-political Culture of Ukrainian Society in Galicia (The Problem of External Models]. Visnyk Lvivskoho universytetu. Seriia istorychna. Lviv, iss. 38, pp. 115-147 (in Ukrainian).

Nakhlik, Ye. (1994). Panteleimon Kulish i "Rus'ka triitsia". Do problemy ideolohichnykh shukan sered ukrains'koi intelihentsii XIX stolittia [Panteleimon Kulish and "Ruthenian Trinity". To the Problem of Ideological Searches among the Ukrainian Intelligentsia of the $19^{\text {th }}$ Century]. Lviv (in Ukrainian).

Nakhlik, Ye. (2007). Panteleimon Kulish: Osobystist', pys'mennyk, myslytel' [Panteleimon Kulish: Personality, Writer, Thinker]. In 2 vol. Kyiv, vol. 1: Zhyttia Panteleimona Kulisha: Naukova biohrafiia (in Ukrainian).

Novynky. [Novelties]. (1861). Slovo, ch. 43, 28 yuniia (10 yuliia), p. 252 (in Ukrainian).

Novynky. [Novelties]. (1861). Slovo, ch. 44, 1 (13) yuliia, p. 256 (in Ukrainian).

Novynky. [Novelties]. (1862). Slovo, ch. 91, 17 (29) noemvriia, p. 356 (in Ukrainian).

Novynky. [Novelties]. (1863). Slovo, ch. 33, 27 aprelia (9 maia), p. 134 (in Ukrainian).

Novynky. [Novelties]. (1863). Slovo, ch. 54, 10 (22) yuliia, p. 216 (in Ukrainian).

Novynky. [Novelties]. (1863). Slovo, ch. 55, 13 (25) yuliia, p. 220 (in Ukrainian).

Ohnennyi zmii. Povist' P. Kulisha [The Fiery Serpent. Story of P. Kulish]. (1841). Kievlianyn. M. Maksymovych. Kiev, kn. II, pp. 181-288 (in Russian).

Ohnianyi zmii. Ukrainska povist' P. Kulisha [The Fiery Serpent. Ukrainian Story of P. Kulish]. (1862).

Ks. Kl. (Perelozhyv z rossiiskoho). Vechernytsi, ch. 20, 14 chervnia, pp. 155-159; ch. 21, 21 chervnia, pp. 170-174; ch. 22, 28 chervnia, pp. 185-190; ch. 23. 5 lyptsia, pp. 203-205; ch. 24, 12 lyptsia, pp. 209-213; ch. 25, 19 lyptsia, pp. 217-220; ch. 26, 26 lyptsia, pp. 225-228 (in Ukrainian).

Otvet sovremennoi letopysy Russkaho Vestnyka [Answer to the modern chronicle of the "Russian Herald"]. (1861, Fevral'). Osnova, pp. 256-259 (in Russian).

Otvit Kostomarova na nekotoryi lzheucheniia zhurnalystov pol'skykh [Kostomarov's Answer to Some False Teachings of Polish Journalists]. (1861). Slovo. Ch. 67. 20 septemvriia (2 oktobriia), pp. 349, 350; Ch. 68. 23 septemvriia (5 oktobriia). pp. 353, 354; Ch. 69. 27 septemvriia (9 oktobriia), pp. 357, 358; Ch. 70.30 septemvriia (12 oktobriia), pp. 361, 362 (in Ukrainian).

Poliakam ob ukrayn'tsakh (Statia P. Kulysha, vyniata yz “Osnovy” II knyzhky za 1862 h.) [For Poles about Ukrainians. (Article by P. Kulish, Taken from the "Osnova", Book II for 1862)]. (1862). Slovo, ch. 80-83, 10 (22) oktobriia - 20 oktobriia (1 noevriia) (in Ukrainian).

Pro horody i sela [About Towns and Villages]. (1862). Vechernytsi, ch. 28, 9 serpnia, pp. 246-248; ch. 29, 16 serpnia, pp. 253, 254; ch. 31, 29 serpnia, pp. 271-272 (in Ukrainian).

Pro horody i sela. Lyst II [About Towns and Villages. Letter II]. (1862). Vechernytsi, ch. 31, 29 serpnia, pp. 271, 272 (in Ukrainian).

Pil'huka, I. I., Chornopys'koho, M. H. (Arranging, preparation of texts). (1965). Pys'mennyky Zakhidnoi Ukrainy 30-50-kh rokiv XIX st. [Writers of Western Ukraine in the 30-50s of the 19th Century]. Kyiv (in Ukrainian).

Raikivskyi, I. (2015). Vnesok Panteleimona Kulisha u vydannia l'vivs'koho zhurnalu "Pravda" (1867 pochatok 1870-kh rokiv) [The Contribution of Pantelejmon Kulish to the Edition of Lviv Periodical "Pravda"(1867 - early 1870's)]. Ukraina: kulturna spadshchyna, natsionalna svidomist', derzhavnist'. Vyp. 27: Yuvileinyi zbirnyk na poshanu Yuriia Slyvky. Lviv, pp. 69-82 (in Ukrainian).

Raikivskyi, I. (2015). Vzaiemyny P. Kulisha z halychanamy v 1870-kh rr. [Relationship between P. Kulish and Galicians in 1870's]. Naukovi zapysky Ternopil'skoho natsionalnoho pedahohichnoho universytetu imeni Volodymyra Hnatiuka. Seriia: istoriia. Ternopil', iss. 1, ch. 1, pp. 44-50 (in Ukrainian).

Shaskevych, V. (1862, Lypets' (iiul')). Nynishnia nasha pisnia (Stykh holoshenyi pry otvoreniu "Rus'koi Besidy" v "Narodnim Domi" vi Lvovi, dnia 9/21 yanvaria 1862 h.) [Our current song (Verse Was Sung at the Opening of the "Ruska Besida"in the "People's House" in Lviv, on January 9/21, 1862)]. Osnova, pp. 69-72 (in Ukrainian).

Shevchenko Institute of Literature. Department of Manuscripts and Textual Studies, m. Kyiv. F. 3 (Franko I. Ia.). Od. zb. 4230. 196 p. (in Ukrainian). 


\section{Проблеми нової і новітньої історії}

Shevchenko Institute of Literature. Department of Manuscripts and Textual Studies, m. Kyiv. F. 104 (Holovatskyi Ya.). Od. zb. 242. 2 p. (in Ukrainian).

Shevchenko Institute of Literature. Department of Manuscripts and Textual Studies, m. Kyiv. F. 104. Od. zb. 243. 1 p. (in Ukrainian).

Shevchenko Institute of Literature. Department of Manuscripts and Textual Studies. m. Kyiv. F. 104. Od. zb. 689. 2 p. (in Ukrainian).

Shevchenko Institute of Literature. Department of Manuscripts and Textual Studies. m. Kyiv. F. 104. Od. zb. 690. 2 p. (in Ukrainian).

Slavianskaia byblyohrafiia [Slavic Bibliography]. (1862). Halychanyn. Lyteraturnyi sbornyk. Lvov, kn. 1, iss. 1, pp. 187-190 (in Ukrainian).

Slovo do nashykh predplatyteliv [A word to our subscribers]. (1862). Vechernytsi, ch. 35. 1 lystopada, p. 296 (in Ukrainian).

Sochyneniia y yzdaniia Nykolaia Yvanovycha Kostomarova [Compositions and Editions of Nikolai Ivanovich Kostomarov]. (1863). Halychanyn. Lyteraturnyi sbornyk. Lvov, kn. I, iss. II, pp. 161-163 (in Ukrainian).

Sovremennaia yuzhnorusskaia lytopys' [Modern South Russian Chronicle]. (1862. Sichen'). Osnova, pp. 81-110 (in Russian).

Studynskyi, K. (1928). Do istorii vzaiemyn Halychyny z Ukrainoiu v rr. 1860-1873 [To the History of Galicia's Relations with Ukraine in 1860-1873]. Ukraina. Naukovyi dvokhmisiachnyk ukrainoznavstva. Kyiv, kn. 2, pp. 6-40 (in Ukrainian).

Studynskyi, K. (1928). Slidamy Kulisha [in the Footsteps of Kulish]. Zapysky NTSh. Pratsi istorychnofilolohichnoi sektsii. Lviv, vol. CXLVIII, pp. 241-306 (in Ukrainian).

Studynskyi, K. (1929). Zviazky Oleksandra Konyskoho z Halychynoiu v rr. 1862-1866 [Oleksandr Konyskyi's Connections with Galicia in 1862-1866]. Zapysky NTSh. Lviv, vol. CL, pp. 271-338 (in Ukrainian).

Studynskyi, K. (1931). Halychyna y Ukraina v lystuvanni 1862-1884 rr. Materiialy do istorii ukrainskoi kultury $v$ Halychyni ta yii zviazkiv z Ukrainoiu [Galicia and Ukraine in the Correspondence of 1862-1884. Materials on the History of Ukrainian Culture in Galicia and Its Relations with Ukraine]. Kharkiv; Kyiv (in Ukrainian).

Sukhyi, O. (2003). Vid rusofilstva do moskvofilstva (rosiiskyi chynnyk u hromadskii dumtsi ta suspilnopolitychnomu zhytti halytskykh ukraintsiv u XIX stolitti) [From Russophilia to Moscvophilia (Russian Factor in Public Opinion and Socio-political Life of Galician Ukrainians in the 19th century)]. Lviv. (in Ukrainian).

Svoezhytevyi zapysky Bohdana A. Didytskoho. Ch. I: Hde-shcho do ystoriy samorozvytiia yazyka $i$ azbuky Halytskoi Rusy [His Own Notes of Bogdan A. Diditsky. Part I: Something to the History of Selfdevelopment of the Language and Alphabet of Galician Russia]. (1906). Lvov (in Ukrainian). Ukrainian).

Terezovskyi, M. (1862). Z Ukrainy [From Ukraine]. Vechernytsi, ch. 33, 13 veresnia, p. 286 (in

Ukraynska slovesnost [Ukrainian Literature]. (1862). Halychanyn. Lyteraturnyi sbornyk. Lvov, kn. 1, iss. 1, pp. 190-193 (in Ukrainian).

Vasyl Stefanyk National Scientific Library of Ukraine in Lviv. Manuscripts Department. F. 36 (Holovatskyi Ya.). Od. zb. 213. 2 p. (in Ukrainian).

Vasyl Stefanyk National Scientific Library of Ukraine in Lviv. Manuscripts Department. F. 36. Od. zb. 508.2 p. (in Ukrainian).

Vendliand, A.-V. (2015). Rusofily Halychyny. Ukrainski konservatory mizh Avstriieiu ta Rosiieiu, 1848-1915 [Russophiles of Galicia. Ukrainian Conservatives between Austria and Russia, 1848-1915. Kh. Nazarkevych (Trans.). Lviv (in Ukrainian). Ukrainian).

Veshniak, T. (1862). Do zemliachky [To the Countrywoman]. Osnova, Liutyi, pp. 81, 82 (in Ukrainian).

Veshniak, T. (1863). Do zemliachky [To the Countrywoman]. Vechernytsi, ch. 5, 31 sichnia, p. 33 (in

Vozniak, M. (1923). Lystuvannia Panka Kulisha z Oleksandrom Konyskym [Correspondence of Panko Kulish with Oleksandr Konyskyi]. Nova Ukraina. Misiachnyk pys'menstva, mystetstva, nauky i hromads'koho zhyttia. V. Vynnychenka, M. Shapovala (Ed.). Praha; Berlin, ch. 7-8, Lypen'-serpen', pp. $267-276$ (in Ukrainian).

Vozniak, M. (1911). Nedrukovana avtobiohrafiia Volodymyra Shashkevycha. [Unpublished Autobiography of Volodymyr Shashkevych]. Nedilia, no. 35, 10 veresnia, p. 6 (in Ukrainian).

Vsiachyna [Everything]. (1863). Vechernytsi, ch. 5, 31 sichnia, p. 40 (in Ukrainian).

Yak hadae Osnova pro halytsku pysmennost'? [What does "Osnova" think about Galician writing?]. (1862). Vechernytsi, ch. 27. 2 serpnia, p. 239, 240; ch. 29, 16 serpnia, p. 256 (in Ukrainian). 
Ynshii cholovik. Opovidane P. Kulisha [Another Man. The Story of P. Kulish]. (1862). Perevedene zъ rossiiskoho. Vechernytsi, ch. 27, 2 serpnia, pp. 233-236; ch. 28, 9 serpnia, pp. 241-244; ch. 29, 16 serpnia, pp. 249-252; ch. 30, 23 serpnia, pp. 257-261; ch. 31, 29 serpnia, pp. 267-270; ch. 32, 6 veresnia, pp. 275-278; ch. 33, 13 veresnia, pp. 282-284 (in Ukrainian).

Ystoriia Ukrayny od naidavniishykh chasiv (Pochatok z obshyrniishoho dila P. Kulisha) [History of Ukraine From the Earliest Times (Beginning of the P. Kulish's extensive work)]. (1863). Vechernytsi, ch. 7, 14 liutoho, pp. 51-54; ch. 8, 21 liutoho, pp. 61-63; ch. 9, 28 liutoho, pp. 69, 70; ch. 10, 7 marta, pp. 76-78; ch. 11, 14 marta, pp. 85, 86 (in Ukrainian).

Za te, od-choho u mistechku Voronezhi vysokh Pishevtsiv stav. Ukraynske opovidane P.Kulisha. [About Those, Why in the Town of Voronezh, the Peshevtsy Pond Has Dried Up. Ukrainian Story by P. Kulish]. (1862). Vechernytsi, ch. 19, 7 chervnia, pp. 145-148 (in Ukrainian).

$\mathrm{Za}$ te, shcho stalosia s kozakom Burdiuhom na Zelenii nedili. Narodne opovidane P. Kulisha [About What Happened to the Cossack Burdyug on Green Sunday. Folk Story by P. Kulish] (1862). (perevedene Zъ velykoruskoho). Vechernytsi, Ch. 36, 8 lystopada, pp. 310, 311; ch. 37, 15 lystopada, pp. 319, 320 (in Ukrainian).

Zabotsen, P. (1861, Noiabr'-dekabr'). Hordovyta para (Babusyne opovidannia) [Proud Couple (Grandma's Story)]. Osnova, pp. 49-56 (in Ukrainian).

Zabotsen, P. (1862). Hordovyta para (Babusyne opovidania) [Proud Couple (Grandma's Story)]. Vechernytsi, ch. 43, 28 hrudnia, pp. 361-364 (in Ukrainian). Ukrainian).

Zaprosyny do peredplaty [Subscription Requests]. (1862). Vechernytsi. ch. 42, 19 hrudnia, p. 360 (in 